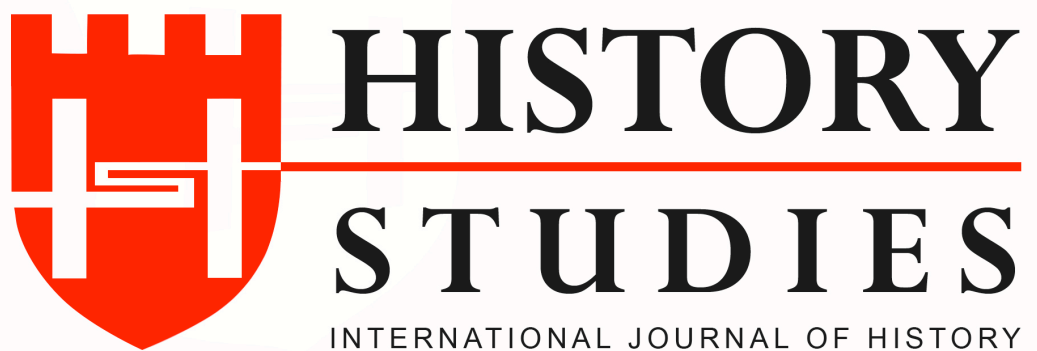

ISSN: 13094173 (Online) 1309 - 4688 (Print)

Volume 11 Issue 5, October 2019

DOI Number: 10.9737/hist.2019.787

Araştırma Makalesi

Makalenin Geliş Tarihi: 01.08.2019 Kabul Tarihi: 30.09.2019

Atıf Künyesi: M. Sait Türkhan, “Osmanl1-İngiliz Ticaret Tarihinin İngiliz Arşiv Kaynakları: State Papers Tasnifi Üzerine Bir Değerlendirme”, History Studies, 11/5, Ekim 2019, s. 1753-1772.

\title{
Osmanlt-İniliz Ticaret Tarihinin Ingiliz Arşiv Kaynakları: State Papers Tasnifi Üzerine Bir Değerlendirme
}

\author{
Archival Sources of Ottoman-British Commercial Relations History: \\ An Evaluations of State Papers Classification
}

\author{
Dr. M. Sait Türkhan \\ ORCID No: 0000-0001-6598-2509 \\ İstanbul Üniversitesi
}

$\ddot{O z z}$

Osmanl1-İngiliz ilişkilerine dair araştırmalar son yıllarda yeniden artış göstermektedir. Bu ilgi yönelimi İngiliz Ulusal Arşivi (The National Archives=TNA)'nde muhafaza edilen Osmanlı tarihi ile ilgili belgeleri daha da dikkat çekici hale getirmiştir. Söz konusu arşiv iki ülke arasındaki diplomatik ve ticari ilişkiler için önemli miktarda belge barındırmaktadır. Diplomatik ilişkiler yanında özellikle Osmanlı limanlarında ve şehirlerinde ticaret yapan Levant Company tüccarlarının faaliyetlerini bu arşiv belgeleri üzerinden incelemek de mümkün olmaktadır. İki devlet arasındaki ilk ilişkilerin tesis edildiği 1580'den itibaren İstanbul elçiliği ve Osmanlı şehirlerindeki konsolosluklar, İngiliz hariciyesi ve Levant Company merkezinden yapılan karşılıklı yazışmalar bu arşiv belgelerinin esasını oluşturmaktadır. Bu birikim 1780'lere kadar devam eden dönem için TNA'de State Papers (SP.) adı verilen tasnifte muhafaza edilmektedir. Bu tasnif kendi içinde üç alt tasnife ayrılmıştır. Bu makalede SP. tasnifindeki bu arşiv belgelerin konularına göre tasnifi ve tanıtımı ile içerik analizleri, 18. yüzyıl ağırlıklı olmak üzere Osmanlı-İngiliz ticari ilişkileri bakımından kaynak değerleri incelenecektir.

Anahtar Kelimeler: Osmanlı-İngiliz ilişkileri, The National Archives (TNA), Levant Company, State Papers (SP.).

\section{Abstract}

The number of researches on Ottoman-British relations has been increasing remarkably in recent years. This increasing interest has made the documents about Ottoman history preserved in The National Archives (TNA) more noteworthy. Many documents about diplomatic and commercial relations between the two countries are available at TNA where it is also possible to examine the activities of the Levant Company merchants, especially in the Ottoman ports and cities. The correspondences of the British Istanbul Embassy starting from its foundation in 1580, the British consulates in the Ottoman cities, the British Ministry of Foreign Affairs, and the Levant Company center form the basis of these archival sources. All these documents in TNA about the relations of the countries until the 1780s are preserved under the classification called State Papers (SP.) which is divided into three sub-categories. This article describes SP. classification and content analysis of these archive documents according to their subjects, their content analysis, and the source values in terms of Ottoman-British trade relations, especially in the 18th century.

Keywords: Ottoman-British relations, The National Archives (TNA), Levant Company, State Papers (SP.). 


\section{Gíriş}

Osmanlı-İngiliz diplomatik ve ticari ilişkileri 1575 y1lında başlayan ilk temaslar ${ }^{1}$ ve bir dizi müzakere sonunda 1580 yılında Osmanlı sultanı III. Murad tarafindan verilen ve 1583 yılında uygulamaya giren ahidname ile başlamıştır ${ }^{2}$. Ahidnameler Osmanlı Devleti'nin Avrupalı devletlerle olan ilişkilerini düzenleyen tek taraflı diplomatik hukuki metinler olup başta payitaht İstanbul olmak üzere Osmanlı limanlarında ve şehirlerinde bulunan Avrupalı devletlerin diplomatik ve ticari temsilcilerine diplomatik ve ticari imtiyazlar sağlamışlardır ${ }^{3}$. Osmanl1-İngiliz diplomatik ve ticari ilişkilerinin hukuki temellerini ortaya bu metinler dışında, ticari ilişkileri uygulama bakımından incelememizi sağlayan başka Osmanlı ${ }^{4}$ ve İngiliz kaynakları da mevcuttur. İlk Osmanl-İngiliz ticari ve diplomatik ilişkilerinin bir diğer sonucu ise İngiltere'de Kraliçe Elizabeth tarafından bir imtiyaz ile desteklenen ve kısa zamanda Akdeniz ticaretinde tekel haklarına sahip olacak bir şirketin kuruluşu olmuştur. 1581'de kurulduğunda ilk ad1 "Turkey Company" olan bu şirket, 1592'de bir başka ticari tekel haklarına sahip "Venice Company" ile birleşerek "The Governor and Company of Merchants of the Levant" veya bilinen kısa adıyla "Levant Company" şeklini almıştır. Levant Company’nin tekel hakları 1821 yılına kadar sürmüş ve şirket 1825 yılında kapanmıştır ${ }^{5}$. Levant Company sahip olduğu tekel hakları çerçevesinde tüm tarihi boyunca Osmanl-İngiliz diplomatik ve ticari ilişkilerinde etkin bir kurum olmuştur.

İngiliz arşivleri dünyanın sayılı arşivleri arasında olup gerek barındırdığı belge kolleksiyonlarının çeşitliliği ve gerekse dünyanın farklı bölgelerinin tarihi ile ilişkili belgelere sahip olması bakımından tarih araştırmaları için başvurulan önemli arşivlerin başında gelmektedir. Daha önceleri Public Record Office (PRO) olarak adlandırılırken, günümüzde resmi adı The National Archives (TNA) olan Londra'daki İngiliz ulusal arşivinde 16. yüzyıl sonlarından başlayıp Osmanlı devletinin yıkılışına kadar geçen süreci kapsayan ve Modern Türkiye tarihini de ilgilendiren belgeler bulunmaktadır ${ }^{6}$. İngiliz Ulusal Arşivi ve bazı önemli

\footnotetext{
${ }^{1} \mathrm{Bu}$ ilk ilişkiler Edward Osborne ve William Harborne adına tüccar Joseph Clements'in şahsi girişimleri ile başlamış olup devletlerarası bir mahiyet arz etmemektedir. Ancak bu tüccarların devam eden girişimleri, Kraliçe I. Elizabeth'in de desteği sonrasında Sultan III. Murad tarafından verilen ahidname anlaşması ile sonuçlanacağı için önemlidir. 1575'teki bu ilk ticari girişim için bakınız; Alfred C. Wood, A History of the Levant Company, Frank Cass\&Co., London 1964; s. 7-8.

${ }^{2} 1575$ yılında başlayan ve 1583 yılında Kraliçe Elizabeth tarafından gönderilen ilk İngiliz elçisinin Osmanlı Sultanı III. Murad tarafından kabulü ile başlayan sürecin ayrıntıları için bakınız; Mübahat S. Kütükoğlu, Balta Limanı'na Giden Yol: Osmanl--ingiliz İktisadi Münasebetleri (1580-1850), TTK. yay, Ankara 2013.

${ }^{3}$ Ahidnameler hakkında bakınız; Halil İnalcık, "İmtiyâzât (The Otoman Empire)", Encyclopedia of Islam, c. III, E. J. Brill, Leiden 1986, s. 1179-1189; Mübahat S. Kütükoğlu, "Ahidname (Türk Tarihi)", Diyanet İslam Ansiklopedisi (DIA), c. I, İstanbul 1988, s. 536-540.

${ }^{4} \mathrm{Bu}$ alandaki Osmanlı kaynaklarının başında düvel-i ecnebiye defterleri gelmektedir. Ahidname uygulamalarında karşılaşılan ticari ve diplomatik sorunların çözümlerini içermesi bakımından Düvel-i Ecnebiye defter ve belgeleri önemlidir. Başbakanlık Osmanlı Arşivi'nde bulunan Düvel-i Ecnebiye defterleri ve belgeleri hakkında bakınız; Başbakanlık Osmanlı Arşivi Rehberi, Haz. Yusuf ihsan Genç, vd., Başbakanlık Basımevi, İstanbul 2010, s. 41-46, 49 ve 276. İngiliz Düvel-i Ecnebiye defterlerine dayalı çalışmalar için bakınız; Hakan Yazar, "Düvel-i Ecnebiye Defterleri: Oluşum Süreci, İçeriği ve İngiltere'ye ait XVIII. Yüzyıl Defterleri”, Diplomasi ve Dış Politika Araştırmalarında Arşivlerin Rolü Uluslararası Sempozyumu Bildiriler, Haz. Duygu Türker Çelik, Aslı Akdoğanbulut İnsan, Ankara 2017, s. 195-214; Mehmet Demiryürek, Ottoman Documents on the English in the Ottoman Empire (1700-1800), The Isis Press, İstanbul 2017.

${ }^{5}$ Levant Company'nin kuruluşu ve faaliyetleri hakkında daha ayrıntılı bilgiler için bakınız; Wood, Levant Company; Mortimer Epstein, The Early History of the Levant Company, George Routledge\&Sons Limited, London 1908.

${ }^{6}$ İngiliz arşivlerinin Osmanlı tarihi bakımından önemine çeşitli çalışmalarla daha önceleri de dikkat çekilmiştir. Akdes Nimet Kurat, "İngiliz Devlet Arşivinde ve Kütüphanelerinde Türkiye Tarihine ait bazı malzemeye dair I", Ankara Üniversitesi Dil ve Tarih-Coğrafya Fakültesi Dergisi, c. VII/1 (Mart 1949), s. 1-27; Muhammed Hanefi Kutluoğlu, "İngiliz Devlet Arşivi (PRO) ve Yakın Dönem Osmanlı Tarihi Açısından Önemi”, Osmanlı Araştırmaları, c. XVIII, (İstanbul 1998), s. 225-238; İsmail Altınöz, "Londra The National Archives'de Ankara ile
} 
İngiliz kütüphanelerde Osmanlı Devleti ile ilgili belge ve yazma kolleksiyonlarının bir kısmı Kurat $^{7}$ ve Köprülü ${ }^{8}$ tarafindan da kısmen incelenmiştir. Daha önceleri Türk ve İngiliz tarihçilerin ilgisini çeken Türk-İngiliz ilişkilerine dair bir dizi araştırmadan ${ }^{9}$ sonra, son yıllarda bu alana yönelik yeniden ilgi uyandığı ve TNA'in bu yeni araştırmalar için sıklıkla ziyaret edilen bir merkez haline geldiği müşahade edilmektedir. Bu minvalde yaklaşık son on yılda, iki ülke arasındaki diplomatik ve ticari ilişkilerin tarihi ile özellikle de Levant'ın çeşitli merkezlerdeki İngiliz ticari varlığın ${ }^{10}$ ve iki ülke arasındaki ithalat-ihracatı gümrük verilerine dayalı olarak inceleyen yeni çalışmalar dikkat çekicidir. ${ }^{11}$

İlgili Belgeler Üzerine bir Değerlendirme", Tarihte Ankara Uluslar Arası Sempozyumu, Bildiriler Ankara 25-26 Ekim 2011, c. II, Ankara 2012, s. 987-999; Osman Ersoy, "İngiliz Devlet Arşivi (The Public Record Office)", Türk Kütüphaneciler Derneği Bülteni, c. IV/2, Ankara 1955, s. 125-131; Metin Ünver, "Son Dönem Osmanlı Tarihi Araştırmaları Açısından İngiliz Milli Arşivi ve Arşiv Belgelerinin Önemi”, Avrupa Arşivlerinde Osmanlı İmparatorluğu, Edt. Yonca Köksal-Mehmet Polatel, İstanbul 2014, s. 105-121; Mehmet Alaaddin Yalçınkaya, "18. Yüzyılın Son Çeyreğinde İngiliz Arşivinde Bulunan Osmanlı Devleti Hakkındaki Arşiv Belgeleri”, II. Uluslararası Osmanlı Coğrafyası Arşiv Kongresi Bildiriler, c. 1, Ankara 2019, s. 683-700.

${ }^{7}$ Kurat, "İngiliz Devlet Arşivinde ve Kütüphanelerinde Türkiye...".

${ }^{8}$ Orhan F. Köprülü, "Türkler ve Türkiye Hakkında Bilinmeyen veya Az Bilinen İngilizce Kaynaklar", Cumhuriyetin 50. Yılına Armağan, Türk Kültürünü Araştırma Enstitüsü yay., Ankara 1973, s. 159-174.

${ }^{9}$ Honyel Gough Rosedale, Queen Elizabeth and the Levant Company: A Diplomatic and Literary Episode of the Establishment of our Trade with Turkey, Henry Frowde pub., London 1904; G. F. Abbott, Under the Turk in Constantinople; a Record of Sir John Finch's Embassy, 1674-1681, Macmillan and Co., London 1920; Epstein, The Early History of the Levant Company; Wood, Levant Company; Ina S. Russell, The Later History of the Levant Company 1753-1825, (The Victoria University of Manchester, Unpublished PhD Thesis),1935; Gwilym Prichard Ambrose, The Levant Company Mainly from 1640-1753, (Oxford Univeristy Unpublished PhD. Thesis), Oxford 1935; Hamit Dereli, Kraliçe Elizabeth Devrinde Türkler ve İngilizler, Ankara Üniversitesi Dil ve Tarih Coğrafya Fakültesi yay., Ankara 1951; Akdes Nimet Kurat, The Despatches of Sir Robert Suttan Ambassador in Constantinople: 1710-1714, Royal Historical Society, London 1953; Akdes Nimet Kurat, Türk-İngiliz Münasebetlerine Kısa Bir Bakış: 1553-1952, Ankara Üniversitesi Dil ve Tarih Coğrafya Fakültesi yay., Ankara 1952; Henry Lello, The Report of Lello: Third English Ambassador to the Sublime Porte, Babiali Nezdinde Üçüncü İngiliz Elçisi: Lello'nun Muhtırası, Edt. Orhan Burian, Ankara Üniversitesi Dil ve Tarih Coğrafya Fakültesi yay., Ankara 1952; Ralph Davis, Aleppo and Devonshire Square: English Traders in the Levant in the Eighteenth Century, Macmillan pub., London 1967; S. A. Skilliter, William Harborne and the Trade with Turkey 1578-1582: A Documentary Study of the First Anglo-Ottoman Relations, British Academy pub., London 1977; Mübahat S. Kütükoğlu, Balta Limanı'na Giden Yol: Osmanl-İngiliz Iktisadi Münasebetleri (1580-1850), TTK. yay., Ankara 2013; Ali İhsan Bağış, Britain and the Struggle for the Integrity of the Ottoman Empire: Sir Robert Ainslie's Embassy to Istanbul 1776-1794, The Isis Press, İstanbul 1984; Sonia P. Anderson, An English Consul in Turkey: Paul Rycaut at Smyrna, 1667-1678, Clarendon Press, Oxford 1989; Necmi Ülker, "XVII.Yüzyılın İkinci Yarısında İzmir'deki İngiliz Tüccarlarına Dair Ticarî Problemlerle İlgili Belgeler”, Belgeler-Türk Tarih Belgeleri Dergisi, c. XIV/18, (1989-92), Ankara 1992, s. 261-319+44; Elena Frangakis-Syrett, The Commerce of Smyrna in the Eighteenth Century (1700-1820), Centre for Asia Minor Studies pub., Athens 1992; Mehmet Alaaddin Yalçınkaya, The First Permanent Ottoman-Turkish Embassy in Europe: The Embassy of Yusuf Agah Efendi to London (17931797), Eren yay, İstanbul 2002; Edhem Eldem, Daniel Goffman, Bruce Masters, Doğu ile Batı Arasında Osmanlı Kenti: Halep, İzmir ve İstanbul, Tarih Vakfı yay., İstanbul 2003; Uygur Kocabaşoğlu, Majestelerinin Konsolosları: Ingiliz Belgeleriyle Osmanlı İmparatorluğu'ndaki İngiliz Konsolosluklart 1580-1900, İletişim yay., İstanbul 2004.

${ }^{10}$ Nigel Webb, Caroline Webb, Earl and his Butler in Constantinople: The Secret Diary of an English Servant among the Ottomans, I. B. Tauris, London 2009; Maurits H. Van Den Boogert, Kapitülasyonlar ve Osmanlı Hukuk Sistemi: 18. Yüzyılda Kadılar, Konsoloslar ve Beratları, Çev. Ali Coşkun Tuncer, Türkiye İş Bankası Kültür yay., İstanbul 2014; G. R. Berridge, British Diplomacy in Turkey 1583 to Present a Study in the Evolution of Resident Embassy, Martinus Nijhoff Pub., Leiden 2009; Chirtine Laidlaw, The British in the Levant: Trade and Perception of the Ottoman Empire in the Eighteenth Century, I. B. Tauris, London 2010; Michael Talbot, British Ottoman Relations 1661-1807: Commerce and Diplomatic Practice in Eighteenth-Century Istanbul, Boydell Press, Woodbridge 2017; M. Sait Türkhan, 18. Yüzyılda Doğu Akdeniz'de Ticaret ve Haleb, (İstanbul Üniversitesi Sosyal Bilimler Enstitüsü Basılmamış Doktora Tezi), Fatih Gürcan, John Murray'ın İstanbul Büyükelçiliği (1765-1775), (Marmara Üniversitesi Türkiyat Araştırmaları Enstitüsü Basılmamış Doktora Tezi), İstanbul 2014; Despina Vlami, Trading with the Ottomans: The Levant Company in the Middle East, I. B. Tauris, London 2015; Ahmet Büyükaksoy, James Porter'ın İstanbul Büyükelçiliği (1747-1762), (Marmara Üniversitesi Türkiyat Araştırmaları Enstitüsü Basılmamış Doktora Tezi), İstanbul 2016; Abdulmennan Mehmet Altıntaş, Kızıldeniz'den Akdeniz'e:

\section{History Studies}


İstanbul'daki ilk İngiliz elçisi olarak da atanacak William Harborne'un ticari imtiyazlar elde etmek için İstanbul'a yaptığı ilk yolculukların masrafları Kraliçe I. Elizabeth tarafından karşılanmıştı. Ancak Venedik ve Fransa gibi güçlü rakiplere karşı İngiliz ticaretinin bir şirket tarafından yürütülmesinin İngiliz çıkarlarına daha uygun olacağı yönündeki raporları da dikkate alan Kraliçe, 11 Eylül 1581 tarihinde Turkey Company’yi kuran tüccarlara Osmanlı ülkesi ile yürütülecek ticaret için yedi yıllık geçici bir tekel imtiyazı bahşetmiştir. Bu imtiyaz ile Osmanlı limanlarında ticaret yapma hakkı sadece şirkete üye tüccara hasredilmiş bir imtiyaz haline gelmiştir. Dönemin şartları çerçevesinde uzak deniz ticari seferlerinin bu şekilde bir şirket dayanışması ile sürdürülmesi İngiliz ulusal çıkarları için de uygun görülmüştür. Şirket çatısı altında sağlanan dayanışma ve risk paylaşımı ticareti daha kârlı hale getirmekteydi ${ }^{12}$. Şirketin ortakları şirket üyeliğinin sağladığı imtiyazlardan faydalanırken, karşılık olarak da Osmanlı limanlarda ithalat ve ihracat üzerinden konsolosluk harcı ödemek zorundaydılar. İngiliz elçisi ve konsoloslar diplomatik ve ticari olarak İngiliz milletinin çıkarlarını savunurken, bu diplomatlar ve diğer diplomatik memurların maaşları ile hediye ve avania gibi yüksek maliyetli diplomatik masraflar şirket tarafından ödenmekteydi. Levant Company tarafindan önerilen ve kraliyet tarafından atamaları gerçekleştirilen diplomatlar siyasi olarak İngiliz tahtını, ticari olarak da Levant Company'yi temsil etmekteydi. İlk Ahidname'nin 1583 yılında uygulamaya girmesi ile ilk İngiliz elçisi William Harborne, aynı yıl içinde Mısır, İskenderiye ve yakın çevresi için bir konsolos, Trablusşam merkez olmak üzere Halep, Şam, Kudüs, ve diğer Suriye limanları için bir konsolos, Cezayir, Trablusgarb ve Tunus ve Sakız adası için de ayrıca birer konsolos atamıştır ${ }^{13}$. Bu tarihten itibaren Londra, elçilik ve konsolosluklardaki yazışmalar ile konsolos, yetkili memurlar ve tüccarların katılımı ile oluşan konsolosluk meclisleri ve mahkemelerinde alınan tüm kararların ve yazışmaların kayı altına alındığı bir belge birikimi oluşmaya başlamıştır. Benzer şekilde, Londra'dan Osmanlı başkentine gönderilen kraliyet mektupları, Levant Company merkezi idaresi tarafından alınan tüm kararlar ile elçilik ve konsolosluklar arasında yapılan tüm yazışmalardan oluşan bir belge küllliyatı meydana gelmiştir. Şirketin elçi ve konsoloslar üzerinden diplomasi ile doğrudan ilgili oluşu ve elçi ve konsolosların maaşlarını ödemesi dışında, konsolosların aynı zamanda şirket üyesi tüccarlar arasından atanması ve asıl meşgul oldukları konuların ticari meselelerden ibaret olması nedeniyle bu belge varlığının büyük bir kısmı doğrudan ticaret ile ilgilidir. İşte Levant Company'nin Londra merkezi ve deniz aşırı temsilciliklerinde tutulan tüm bu kayıtlar Osmanlı limanlarında ticaret yapan İngiliz tüccarlar hakkındaki birincil kaynakların başında gelmektedir. Bu kayıtlar günümüzde TNA'de Secretary of State Office'in belge ve defterlerinin muhafaza edildiği State Papers (SP.) tasnifinde bulunmaktadır.

Ticaret, Diplomasi ve Güzergâhlar (1600-1700), (İstanbul Üniversitesi Sosyal Bilimler Enstitüsü, Basılmamış Doktora Tezi), İstanbul 2016.; Uzeyir Serdar Serdaroğlu, The Evolution of Commercial Institutions and Business Networks in the Ottoman Empire: British Merchant Families and Individual Merchants in the Levant Trade in the 18th Century, (University of Birmingham Unpublished PhD Dissertation), Birmingham 2018; Ahmet Büyükaksoy, “İngiltere'nin İstanbul Elçisi Sir Everard Fawkener'in Kaleme Aldığı 1731-1738 Yılları Arasındaki Hadiseleri Anlatan Bir Rapor", Yeditepe Üniversitesi Tarih Bölümü I. Uluslararası Türk Kültürü ve Tarihi Sempozyumu Bildiri Kitabl, Ed. Ahmet Taşağıl, Aykut Kar, Ahmet Büyükaksoy, Ayşen Müderrisoğlu, yy., ty., s. 452-472, https://www.academia.edu/39833534/\%C4\%B0NG\%C4\%B0LTERE N\%C4\%B0N \%C4\%B0STANBUL EL\%C3 $\% 87 \% \mathrm{C} 4 \% \mathrm{~B} 0 \mathrm{~S} \% \mathrm{C} 4 \% \mathrm{~B} 0 \quad \mathrm{~S} \% \mathrm{C} 4 \% \mathrm{~B} 0 \mathrm{R}$ EVERARD FAWKENER \%C4\%B0N KALEME ALDI\%C4\%9EI 173 1-1738 YILLARI ARASINDAK\%C4\%B0 HAD\%C4\%B0SELER\%C4\%B0 ANLATAN B\%C4\%B0R RAPOR, (E.T. 12 Temmuz 2019).

${ }^{11}$ Osmanlı-İngiliz ithalat-ihracatı üzerine Londra gümrüğü verilerine dayalı bir araştırmanın ilk sonuçları için bakınız; Numan Elibol, Erol Özvar, "The Anglo-Ottoman Trade 1700-1800: Goods, Volume and Balance of Trade", https://ata.boun.edu.tr/ahec/conferencepapers2014/ElibolOzvar.pdf (E.T. 20 Mart 2016).

${ }^{12}$ Wood, Levant Company, s. 11-12.

${ }^{13}$ Wood, Levant Company, s. 15. 
İngiliz merkezi bürokrasisi içinde önemli bir yer işgal eden Secretary of State bürosu, kraldan sonraki en önemli karar alma ve uygulama mekanizmalarının başında gelmektedir. Önceleri görev ve sorumluk alanı sadece dışişleri olan büroya 16. yüzyılda içişleri de dahil edilmiş ve Secretary of State bürosu 1782'ye kadar İngiltere'nin gerek içişlerinde gerekse diplomasi ve sömürgecilik alanlarındaki faaliyetlerinin yönetim bürosu olmuştur ${ }^{14}$. Bu özellikleri itibariyle büronun arşivindeki belge varlığı erken modern dönem İngiliz tarihi için büyük önem arz etmektedir ${ }^{15}$. Kuzey ve güney olarak ikiye ayrılan bu büronun kuzey şubesi Kuzey Avrupalı protestan devletler ile ilişkileri yürütürken, güney şubesi katolik Avrupa devletleri de dahil diğer devletlerle olan ilişkilerden ve içişlerinden sorumluydu. $\mathrm{Bu}$ iki büronun başında iki farklı Secretary of State görev yapmıştır. 1782'de bu bölümlerden Secretary of State South, Home Office'e, Secretary of State North ise Foreign Office'e dönüşmüşler ve diş ilişkiler Foreign Office tarafından yürütülmeye başlanmıştır ${ }^{16}$. Bu bürokratik değişimden önce 1764'te State Papers Office arşivinde birikmiş belgelerin tasnif edilmesi, özetlenip indekslenmesi ve ciltlenerek koruma altına alınması yönünde bazı çalışmalar yapılmıştır. Ancak bu maksatla oluşturulan komisyon beklenen verimli çalışmayı gerçekleştirememiştir ${ }^{17}$. 1800 'de çalışmalara yeniden başlanmış ve yeniden oluşturulan komisyonun faaliyetleri ${ }^{18}$ çerçevesinde $1825^{\prime}$ de SP. içinden seçilen bölümlerin bir dizi halinde yayınlanmasına karar verilmiştir. Bu çalışmalar sonucunda 1830 ' da ilk cilt yayınlanmışıır ${ }^{19}$. Bu ilk cildi takiben 1852 yılına kadar toplam 11 cilde ulaşan State Papers kolleksiyonundan seçme yazışmalardan oluşan bir belge külliyatı ortaya çıkmışıır ${ }^{20}$. Bu 11 ciltlik külliyat tarih aralığı olarak VIII. Henry'nin saltanatının 9. yılından yani 1518'den başlayıp, ölüm tarihi olan Ocak 1547 tarihine kadar olan dönemi kapsamaktadır. Bu külliyatta Osmanlı tarihini ilgilendiren belgeler de bulunmaktadır. Bu belgeler henüz iki devlet arasında diplomatik ilişkinin tesis edilmediği bir dönemde Londra'nın belirli aralıklarla Osmanlıların Avrupa'daki ve Akdeniz'deki askeri faaliyetleri ile İstanbul ahvaline ait haberleri Venedik ve Paris'teki İngiliz elçileri üzerinden takip ettiğini göstermektedir. Bu haberler içinde özellikle Osmanlıların Avusturya ve Macaristan'a yönelik siyasetleri ile Viyana kuşatması, Preveze deniz savaşı ve Barbaros'un Nice kuşatması gibi hadiseler daha ayrıntılı olarak yer bulmuştur ${ }^{21}$. Bu serinin kaldığ yerden, ilk cildi 1861'de basılan Calendar of State Papers Foreign Series yayınlanmıştır.

\footnotetext{
${ }^{14}$ State Papers bürosunun kuruluşu ve yönetimi ile 17. yüzyıla ait defterlerinin içeriklerine dair kısa açıklamalar için bakınız; S. C. Lomas, "The State Papers of the Early Stuarts and the Interregnum", Transactions of the Royal Historical Society, New Series, vol. XVI, (1902), s. 97-132.

${ }^{15}$ State Papers Bürosu arşivinin 17. yüzyılda tarih yazımında kaynak olarak kullanımı hakkında bakınız; Michael Riordan, "The State Papers and the Writing of History in Early Seventeenth Century England", (edt. Maria Pia Donato, Anne Saada), Pratiques d'Archives à l'époque Moderne. Europe, Mondes Coloniaux, s. 69-93, Doi: 10.15122/isbn.978-2-406-08555-3.p.0069, (E.T. 12 Temmuz 2019).

${ }^{16}$ Alexander Wood Renton vd., (ed.) Encyclopcedia of the Laws of England with Forms and Precedents by the Most Eminent Legal Authorities, vol. XIII, William Green and Sons, Edinburgh 1908, s. 202.

${ }^{17}$ State Papers Published under the Authority of his Majesty's Commission, vol. I, John Murray pub., London 1831, s. $\mathrm{xx}$.

${ }^{18}$ Record Commission olarak adlandırılan bu ikinci komisyonun faaliyetleri hakkında bakınız; Peter Walne, "The Record Commission 1800-37", Prisca Munimenta. Studies in Archival and Administrative History presented to Dr. A. E. J. Hollaender, Edt. Felicity Ranger, University of London press., London 1973.

${ }^{19}$ Charles Purton Cooper, An Account of the Most Important Public Records of Great Britain and the Publications of the Record Commissioners together with other Miscellaneous Historical and Antiquarian Information Compiled from Various Printed Books and Manuscripts, vol II, Baldwin and Cradock, London 1832, s. 390. İlk cilt: State Papers Published under the Authority of his Majesty's Commission, vol. I, John Murray pub., London 1831.

20 11. cilt için bakınız; State Papers Published under the Authority of her Majesty's Commission, vol. XI, London 1852.

${ }^{21}$ State Papers Published under the Authority of her Majesty's Commission, vol. IX, London 1849.
}

\section{History Studies}


$\mathrm{Bu}$ serinin ilk cildi 1547-1553 yıllarını kapsamaktadır ${ }^{22}$. SP. kolleksiyonuna ait bu belge yayınları dışında 1579-1779 arası dönem İngiliz-Osmanlı diplomatik ve ticari ilişkilerine ait belgelerin hemen hemen tamamı TNA'de SP. ${ }^{23}$ tasnifinde, 1780 ve sonraki belgeler ise Foreign Office $^{24}$ (FO.) 78 tasnifinde muhafaza edilmektedir ${ }^{25}$.

$\mathrm{Bu}$ çalışmada, günümüzde TNA'de muhafaza edilmekte olan SP. tasnifindeki arşiv belgelerinin konularına göre tanıtımı, içerik analizleri, 18. yüzyıl ağırlıklı olmak üzere Osmanlı-İngiliz ticari ilişkileri bakımından içerikleri ve kaynak değerlerleri ayrıntılı olarak ele alınmıştır. SP. tasnifinde Osmanlı-İngiliz ilişkilerine ait SP. 97, SP. 105 ve SP. 110 olmak üzere üç alt tasnif vardır ${ }^{26}$.

\section{STATE PAPERS (SP.) 97}

SP. tasnifi içindeki İngiliz hariciyesi ile ilgili belgelerinden 1509-1577 arası döneme ait belgelerler sirasiyla VIII. Henry, VI. Edward, Mary, I. Elizabeth'in saltanat dönemlerine göre tasnif edilmiştir. 1577 'den sonraki belgeler ise ilgili devletlere göre tasnif edilmiştir. Osmanlı Devleti ile ilgili belgeler ise, Kraliçe I. Elizabeth dönemine ait olan (SP. 70) tasnifi dişında, "SP. 97 (Turkey)" tasnifindedir. SP. 97 tasnifi 1579-1779 yıllarını kapsamakta ve toplam 60 ciltten müteşekkildirr ${ }^{27}$. Bu tasnif ağırlıklı olarak İstanbul'daki elçilerin Londra'ya gönderdikleri raporları ile elçi ve konsolosların kraliyet ve Secretary of State ile olan diplomatik yazışmalarını ihtiva etmektedir. Bu raporların kimisi kapsadıkları süre ve içerik bakımından oldukça tafsilatlıdır ${ }^{28}$. İngiliz Elçisi Robert Sutton'un 1710-1712 arasında İstanbul'dan yazdığ 1 SP. 97/22 ve SP. 97/23'teki raporlar ve mektuplardan bir kısmı seçme olarak Akdes Nimet Kurat tarafından yayınlanmıştır ${ }^{29}$. Esas itibariyle diplomatik meselelerden ibaret olan SP. 97 içeriğinde ticaret ile ilgili konular da karşımıza çıkar. İstanbul'daki elçilerin Londra'ya gönderdikleri mektupların asıllarından oluşan bu tasnifte zaman zaman konsoloslar tarafından kaleme alınmış mektuplar da bulunmaktadır. Mektupların kahir ekseriyeti İngilizce olmakla birlikte nadiren İtalyanca yazılmış olanları ile yine nadiren bazı Türkçe belgelerin kopyalarına da rastlanmaktadır. Bu tasnifdeki ciltlerin büyük kısmı belgelerin kronolojik olarak bir araya getirilip ciltlenmesi ile oluşmuştur. Bu itibarla kronolojik olarak düzenlidir ve ciltleme genelde

${ }^{22}$ Calendar of State Papers, Foreign Series, of the Reign of Edward VI., 1547-1553, Preserved in the State Papers Department of Her Majesty's Public Record Office, Edt. William B. Turnbull, Longman, Green, Longman, \& Roberts pub., London 1861.

${ }_{23}$ The National Archive (TNA) State Papers (SP.) tasnifinin genel özellikleri hakkında bakınız; http://www.nationalarchives.gov.uk/help-with-your-research/research-guides/state-papers-foreign-1509-1782/ (E.T. 12 Temmuz 2019).

${ }_{24}$ The National Archive (TNA) Foreign Office (FO.) tasnifi hakkında bakını; http://www.nationalarchives.gov.uk/help-with-your-research/research-guides/foreign-commonwealthcorrespondence-and-records-from-1782/

(E.T. 12 Temmuz 2019).

${ }^{25}$ Foreign Office'in kurulduğu 1782 tarihi $F O$. tasnifindeki belgelerin en erken tarihli olanları için kesin bir sınır teşkil etmez. Muhtemelen Foreign Office'e sonraki tarihlerde nakledilen erken tarihli bazı evraklar nedeniyle $F O$. tasniflerinde 1780 öncesine ait belgelere rastlanmaktadır. Örneğin: FO. 881/10007, (Persia\&Turkey: Treaties between Persia and Turkey, 1639-1822) https://discovery.nationalarchives.gov.uk/details/r/C3662690, (E.T. 12 Temmuz 2019) veya FO. 881/280, (Turkey: Abstract. Russia and Turkey. Treaties, 1774-1849), https://discovery.nationalarchives.gov.uk/details/r/C3659811, (E.T. 12 Temmuz 2019).

${ }^{26} \mathrm{Bu}$ üç tasnif dışında özellikle Türkçe belgelerin bulunduğu SP. 102 nolu tasnif daha önce Kurat tarafindan incelendiği için bu değerlendirmeye dahil edilmemiştir. Bakınız; Kurat, "İngiliz Devlet Arşivinde ve Kütüphanelerinde Türkiye...”, s. 7-12.

27 The National Archives katalogunda SP. 97 tansifi hakkında genel bilgi için bakınız; https://discovery.nationalarchives.gov.uk/details/r/C13636, (E.T. 12.06.2019).

${ }^{28}$ Bu tür bir rapor için bakınız; Büyükaksoy, "İngiltere'nin İstanbul Elçisi Sir Everard Fawkener'in ... Rapor".

29 Akdes Nimet Kurat, The Despatches of Sir Robert Sutton Ambassador in Constantinople (1710-1714), Royal Historical Society, London 1953. 
elçilerin görev dönemlerine göre yapılmıştır ${ }^{30}$. Ancak içlerinde cildi dağılmış veya hiç ciltlenmeden dosya şeklinde muhfaza edilmekte olanları da bulunmaktadır ${ }^{31}$. SP. 97'nin kaynaklık ettiği doğrudan Osmanl-İngiliz diplomatik ve ticari ilişkilerini inceleyen çeşitli araştırmalar bulunmaktadır ${ }^{32}$. Ancak iki devlet arasındaki diplomatik ilişkiler üzerinde yeni araştırmalar yapılması gereken alanlardandır.

\section{STATE PAPERS (SP.) 105}

SP. 105 numaralı tasnif karma bir tasnif olup toplam 344 cilt defterden oluşmaktadır ve Levant Company kayıtları dışında İngiltere'nin başka devletler nezdindeki elçilerin merkeze gönderdikleri mektupları ile İngiliz dışişlerinin çeşitli görevler için görevlendirdiği diplomatların rapor ve yazışmalarını da içermektedir ${ }^{33}$. Ancak tasnifin büyük bir kısmı Levant Company Londra merkez idaresinin (General Court) kayıtlardan oluşmaktadır. Tasnifte Levant Company’ye ait 1590-1825 yıllarını kapsayan toplam 113 cilt vardır ve bunların 34 cildi 18 . yüzyıla ait kayıtları ihtiva etmektedir. Bu kayıtlardan mektup türündeki yazışmaların tamamı kopya kayıtlarından oluşmaktadır. SP. 105 içindeki Levant Company kayıtları konuları ve içerikleri itibariyle sekiz farklı grupta incelenebilir ${ }^{34}$.

Birinci grup belgeler Levant Company Londra merkez idaresi ile başta İstanbul'daki elçi ve ticarethanedeki tüccarlar, İzmir, Halep, Kahire, Kıbrıs, İskenderiye gibi diğer liman ve konsolosluk merkezlerindeki konsolos, hazinedar, kançılarya, liman temsilcisi ve tüccarlara gönderilen mektupların kopyalarından oluşmaktadır. 1590-1825 yıllarını kapsayan bu kayıtlar SP. 105/109-SP. 105/142 arasındaki toplam 33 cilttir. Bu yazışmalar ilgili bölgelerdeki İngiliz ticaret ağının yapısı hakkında ayrıntılı bilgi edinmek bakımından oldukça önemli belgelerdir. $\mathrm{Bu}$ defterlerin söz konusu limanlardaki şirket idaresi ve ticaretin genel durumu, yaşanan sorunlar ve bu sorunlara aranan çözüm yolları, piyasa şartları, fiyat hareketlilikleri, diğer millletlerin tüccarları, yerel idareci ve tüccarlarla ilişkiler gibi konulara dair ayrıntılar içerir. Düzenli kopyalandığı anlaşılan bu yazışmalardan Levant Company idaresi ile ilgili limanlar arasında ticarete dair düzenli ve yoğun bir yazışma trafiğinin gerçekleştiği anlaşılmaktadır. Bu yoğunluk özellikle ticaretin yoğunlaştığı, gemi hareketliliklerinin arttığı mevsimlerde, savaş zamanlarında ve örneğin veba gibi salgın hastalık zamanlarında artış göstermektedir. Levant Company idaresi en zayıf veba salgını söylentisinde bile her türlü ihtimali göz önüne alarak limanlarda gerekli tedbirlerin alınmasını anında emretmekteydi. Veba ihtimali olan yerler hemen elçi ve diğer konsoloslara bildirilerek dikkatli olunması emredilmekte ve gerekli tedbirler almadan gemilerin limana yanaşmalarına veya limandan ayrılmalarına izin verilmemesi bildirilmekteydi. Veba salgını olan limanlarda mal yüklemesinin durdurulması ve veba bulunmayan limanlardan ayrılacak gemilere de sağlık belgesi (bill of healty) verilmesini

\footnotetext{
${ }^{30}$ Mektupların bir araya getirilip ciltlenmesi işinin 19. yüzyılın ilk yarısında yapıldığı düşünülebilir. Zira SP. 97/46 numaralı cildin dış kapağının iç kısmına, W. Noël Sainsbury tarafından 1855 yılında eklenmiş bir nota göre, bu ciltte mektupları bulunan elçi Murray’ye ait yazışmaların olduğu cildin başına başka bir yerde rastlanan bazı mektuplar Sainsbury tarafından 1855 yılında eklenmiştir. SP. 97/46, (iç kapak, 18 June 1855).

31 SP. 97/56, SP. 97/57 ve SP. 97/58 ciltlenmeden kalmış ve dosyalanmak suretiyle muhafaza altına alınmış belgelere örnek olarak verilebilir.

32 Wood, Levant Company; Epstein, The Early History of the Levant Company; Daniel Goffman, Osmanll Imparatorluğu'nda Ingilizler 1642-1660, Çev. Ayşe Başç1-Sander, Sabanc1 Üniversitesi yay., İstanbul 2001. Laidlaw, The British in the Levant; Yalçınkaya, The First Permanent Ottoman-Turkish Embassy in Europe; Talbot, British Ottoman Relations 1661-1807; Gürcan, John Murray'ın İstanbul Büyükelçiliği (1765-1775); Büyükaksoy, James Porter'in İstanbul Büyükelçiliği (1747-1762).

33 The National Archives katalogunda SP. 105 tasnifi hakkındaki bilgi için bakınız; https://discovery.nationalarchives.gov.uk/details/r/C13644 (E.T. 12.06.2019).

${ }^{34}$ Söz konusu gruplama arşiv idaresinin yaptığı bir gruplama olmayıp, inceleme maksatlı olarak defterlerin içerik ve konularına göre tarafımızca yapılmıştır.
} 
emretmekteydi ${ }^{35}$. Bu gibi durumlarda aynı içerikteki mektupların birçok merkeze aynı günlerde seri olarak gönderildiği ve tamamının aynen defterlere kopyalandığı görülür.

İkinci guruptaki belgeler idari konulara ait yazışmaların kopyalarını içerir. Bunlar Londra'dan İstanbul ve Osmanlı taşrasındaki diplomatik merkezlere ve tüccarlara bildirilen resmi emirlerin kopyalarıdır. SP. 105/143- SP. 105/146 numaralı 4 ciltte 1605-1778 yılları arasında Levant Company merkez idaresi tarafindan Levant'taki merkezlere İngiliz hükümetinin resmi emirleri ile kanuni değişiklik ve düzenlemeleri bildiren emirlerin kopyaları vardır. $\mathrm{Bu}$ kayıtlar İngiliz hükümetinin şirket ile ilişkileri, şirkete ve ticarete yönelik politikalarını yansitır. SP. 105/209-SP. 105/211 arasındaki 3 ciltte ise 1662-1818 yılları arasında Levant Company idaresinin Osmanlı topraklarındaki tüccarlara ve diplomatlara gönderdiği resmi emirlerin kopyaları vardır. Bu kayıtlar da Levant Company merkez idaresinin deniz aşırı bölgelerdeki temsilcilikleri ile ilişkileri ve ticaret politikalarını göstermesi bakımından önemlidir. Bu 3 cildin bütünleyicisi olarak Levant Company Genel Kurul Kararları Tutanakları (Minute Books of the General Court of the Levant Company) zikredilebilir. Londra'daki şirket merkezinde düzenli olarak toplanan şirket genel kurulunda alınan kararlar Levant'taki temsilcilikler için uyulması gereken bağlayıcı kararlardır ve şirketin ticaret politikalarını yansıtması bakımından önemlidir. Bu tutanaklar 1611-1706 yıllarına ait olup SP. 105/147-SP. 105/156 numalar arasında toplam 10 ciltten müteşekkildir.

SP. 105 tasnifteki üçüncü grup Levant Company Londra merkez bürosunun 17. yüzyıldan 19. yüzyıl ortalarına kadar ki devre ait muhasebe kayıtlarını (Treasurer's Account Books) ihtiva etmektedir. Bu kayıtlar Levant ticaretinin ve şirketin mali ve iktisadi boyutlarını anlamak bakımından önemlidir. Bu kayıtlar arada bazı yılları eksik olmak üzere 1619-1825 yılları arasina ait olup SP. 105/157-SP. 105/165 ile SP. 105/208 ve SP. 105/215 numaralı defterlerden müteşekkil, toplam 11 cilttir.

Dördüncü grup belgeler İstanbul elçiliğinin kançılarya (chancellor) kayıtlarını ihtiva etmektedir. Kançılarya, elçilik ve konsoloslarda görev yapan ve statü bakımından elçi ve konsoloslardan hemen sonra gelen en yetkili katip-memurdur ${ }^{36}$. Diplomatik büronun tüm kayit ve envanter işlemleri, elçilik memurlarının atamaları, elçi ve konsolosluğa başvuran tüm İngiliz uyruklarının ve İngiliz himayesi altındaki diğer millet tebasının adli ve noter işlemleri ile ticari ve diplomatik sorunlara dair elçiliğin yürüttüğü işlemlerin tamamı kançılarya tarafından gerçekleştirilir ve kayıt altına alınırd1 ${ }^{37}$. Diplomatik hiyerarşinin en yetkili katibi olan kançılaryanın kayıtları elçilik ve konsoloslukların idari yapısı ve çalışma düzeni ile Osmanlı bürokrasisiyle olan ilişkiler hakkında bilgi sahibi olmak bakımından önemlidir. Bu yazışmalar içinde diğerlerinden farklı Osmanlı bürokratik mercilerince üretilmiş ahkam, ilam, hüccet gibi çeşitli evrakın kopyalarına da rastlamaktadır. Bu gurupta 1648-1825 yılları arasını kapsayan SP. 105/174-SP. 105/198 arasinda toplam 25 cilt defter bulunmaktadır.

Beşinci grup belgeler, 1730-1816 yıllarını kapsayan SP. 105/202-SP. 105/206 arasında 5 cilt İstanbul elçiliği muhasebesi ile, 1721-1726 yıllarına ait SP. 105/207 numaralı 1 cilt İzmir konsolosluğu muhasebe defterinden oluşmaktadır. Diplomatik temsilciliklerdeki önemli görevliler arasında bulunan hazinedarlar (treasurers) elçilik veya konsolosluğun mali idaresinden ve muhasebe düzeninden sorumluydular ${ }^{38}$. Hazinedarlar şirketin mali işlerinin

\footnotetext{
35 SP. 105/116, Londra'dan Halep'te Konsolosu John Purnel'e, (27 Ocak 1721/7 Şubat 1721). SP. 105/116, Londra'dan İstanbul'a elçi Abraham Stanyan'a, (21 Temmuz 1721/1 Ağustos 1721). SP. 105/116, Londra'dan Halep Konsolos John Purnel'e, (24 Temmuz 1721/4 Ağustos 1721).

${ }^{36}$ Laidlaw, The British in the Levant, s. 32.

${ }^{37}$ Türkhan, 18. Yüzyllda Doğu Akdeniz'de Ticaret ve Haleb, s. 199.

${ }^{38}$ Türkhan, 18. Yüzyllda Doğu Akdeniz'de Ticaret ve Haleb, s. 200.
} 
idarecisi olarak, şirketin önemli gelir kalemleri arasında bulunan İngiliz ve diğer mahmi milletlerin tüccarlardan tahsil edilen ve konsolosluk hakkı olarak anılan komisyonlar ile diğer gelirlerin tahsili, maaş ödemeleri ve diğer yönetim gidelerinin idaresinden sorumluydular. Gelir-gider muhassebesi sonrasında konsolosluk hazinesinde kalan paranın poliçe yoluyla veya nakit olarak İstanbul'daki elçiliğe aktarılması gerekmekteydi. Poliçe, nakitin doğrudan havalesine yönelik güvenlik risklerine karşı sıklıkla başvurulan bir uygulama olup ancak uygun bir poliçe bulmak da her zaman mümkün olmamaktaydı. Öte yandan özellikle 18. yüzyılda Levant'ta İngiliz ticaretin gerilemeye başlamasıyla birlikte düşen şirket gelirleri karşısında hazinedarlar finansal yönetim için kendi bünyesindeki tüccarlardan borç almak zorunda kalmışlardır ${ }^{39}$.

Şirket bütçesine ağır yükler getiren avania ${ }^{40}$ ödemeleri de Londra'daki şirket idaresi ile konsolosluklardaki hazinedarların uzunca süre meşgul edebiliyordu. Zira avania ödemeleri için deniz aşırı bölgelerdeki hazinedarlar şirket merkezinden onay almak durumundaydılar. Aksi takdirde yapılan ödeme usulsüz olurdu ki bu durumda tazmini gerekirdi. Avania ödenmesi geldiğinde bu avanianın Levant'taki tüm İngiliz ulusu üyelerinin ortak çıkarlarını ilgilendirip ilgilendirmediğine bakılarak "milli" kabul edilip edilmeyeceğine ilgili şirket meclisinden gelen öneri doğrultusunda Levant Company merkez yönetimi karar verir ve milli olarak kabul edilen avanialar şirket bütçesinden ödenirdi ${ }^{41}$. Aksi durumlarda ise avania kendisinden talep edilen tüccar tarafından ödenirdi.

Altınc1 grup belgeler 1669-1813 arasını kapsayan SP. 105/166-SP. 105/173 arasında toplam 8 ciltten oluşan ve Levant Company'nin Londra'da ithalat ve ihracat üzerinden şirket adına tahsil ettiği vergi ve komisyon kayıtlarını ihtiva etmektedir. Bu kayıtlar ticaret hacmini tespit bakımından önemli olmakla birlikte mevcut ciltler arasında kronolojik olarak büyük boşluklar mevcuttur.

Yedinci gruptaki belgeler 1622-1775 yıllarına arasındaki muhtelif zamanlarda İstanbul'da elçi olarak görev yapan Thomas Roe ${ }^{42}$, Sackville Crowe ${ }^{43}$ ve John Murray ${ }^{44}$,ye ait yazışmaları içeren SP. 105/102, SP. 105/103, SP. 105/104 nolu üç ayrı ciltten ibarettir. Konuları itibariyle SP. 97 tasnifinde olması gereken bu defterlerin bu tasnife nasıl dahil edildiği belli değildir. Her üç elçinin faaliyetleri hakkında ayrıntılı bilgiler sunan bu defterler elçilik müessesesinin işleyişi ve dönemin olayları ile diplomatik ilişkilerin seyrini takip için zengin kaynaklardır.

Sekizinci grup belgeler ise ilk yedi gruptaki 103 defterden geriye kalan ve farklı tarihlere ait muhtelif ticari ve diplomatik kayıtları içeren toplam 10 cilt defterden ibarettir.

\footnotetext{
${ }^{39}$ Türkhan, 18. Yüzyllda Doğu Akdeniz'de Ticaret ve Haleb, s. 202.

${ }^{40}$ Müstemen tüccarların Osmanlı topraklarındaki avania sorunları hakkında genel olarak bakının: Van Den Boogert, Kapitülasyonlar ve Osmanlı Hukuk Sistemi; s. 113-152.

${ }^{41}$ SP. 105/116, Londra'dan Halep şirket hazinedar William Withfeld'a, (12 Temmuz 1721/23 Temmuz 1721).

42 Thomas Roe'nun hayatı ve Samuel Richardson tarafindan derlenerek 1740 y1linda "The Negotiations of Sir Thomas Roe in his Embassy to the Ottoman Porte, from year 1621 to 1628 Inclusive: Containing a Great Variety of Curious and Important Matters, Relating not only to the Affairs of Turkish Empire, but also to the those of the other States of Europe in that Period; his Correspondences with most Illustrious Persons... and many Useful and Instructive Particulars" adıyla basılmış mektuplar için bakınız; Ahmet Büyükaksoy, İngiltere'nin İstanbul Elçisi Thomas Roe'nun Diplomatik Yazışmaları (1621-1628), (Marmara Üniversitesi Türkiyat Araştırmaları Enstitüsü Basılmamış Yüksek Lisans Tezi), İstanbul 2012.

${ }_{43}$ Sackville Crowe'un elçilik döneminde Osmanlı-İngiliz ilişkileri için bakınız; Goffman, Osmanlı Imparatorluğu'nda Ingilizler 1642-1660.

44 John Murray'nin İstanbul'daki faaliyetleri için bakınız; Laidlaw, The British in the Levant; Gürcan, John Murray'ın İstanbul Büyükelçiliği (1765-1775).
} 


\section{STATE PAPERS (SP.) 110}

SP. 110 tasnifi de SP. 105 numaralı tasnif gibi karma bir tasnif olup toplam 90 ciltten müteşekkildir. Bu tasnifte Levant Company'ye ait toplam 65 cildi defter bulunmaktadır ve bunlardan 54 adedi 18. yüzyıla aittir. Söz konusu defterlerden Levant Company Londra merkez yönetiminin Halep ile ilgili emirlerinden oluşan SP. 110/57, SP. 110/67 ve SP. 110/68 numaralı iki defter ile İngiliz Elçisi John Murray'nin elçilik dönemine ait SP. 110/86 ve 110/87 numaralı iki defter ${ }^{46}$ hariç tamamı Halep konsolosluğunun yazışma kopyaları, Halep'teki ticari acentelere ait yazışmaların kopyaları ile Halep ve İskenderun'daki İngiliz ticari faaliyetlerine ait kayıtlardan oluşmaktadır. SP. 110 tasnifi içerik bakımından dört grupta incelenebilirr ${ }^{47}$.

Birinci grup "Letters book of factor" şeklinde etiketlenmiş olup Halep’teki İngiliz ticari acentelerin Levant Company merkez yönetimi ile Londra'daki patronlarına ve Osmanlı topraklarındaki diğer İngiliz tüccarlar ve konsoloslara gönderdikleri mektuplarının kopyalarından oluşturmaktadır. SP. 110/10-SP. 110/53 arasındaki toplam 44 ciltten oluşan bu ilk grup 1634-1798 yılları arasına ait kayıtları ihtiva etmektedir.

$\mathrm{Bu}$ grupta 18. yüzyıla tarihlenen defterlerin bir kısmı nem veya başka sebeplerden ötürü kısmen tahrip olmuştur ve içlerinde okunması mümkün olmayan ciltlere rastlanmaktadır. Birinci gruptaki defterler içerik olarak Halep konsolosu ve Halep'teki acenteler tarafından başta Levant Company Londra merkez idaresi ile Londra'daki patron tüccarlara, İstanbul'daki İngiliz elçisi ve ticaret acentelerine, İskenderun, Lazkiye, Sayda, Akka, Trablusşam, Kıbrıs'daki konsolos vekilleri ile ticaret acentelerine ve İzmir, Kahire, İskenderiye, Marsilya, Livorno, Venedik, Gambron (Bender-i Abbas), İsfahan ve Surat'ta bulunan İngiliz konsolosları ve ticari acentelere gönderilen mektupların kopyalarından oluşmaktadır. $\mathrm{Bu}$ mektuplar Halep'teki İngiliz tüccarların tüm Akdeniz, Basra ve Hindistan'daki ticaret, ilişki ve haberleşme ağlarını göstermesi bakımından önemlidir. Özellikle fiyat hareketlilikleri ve İngiliz tüccarların Halep'ten aldıkları emtia arasında önemli bir yer tutan ipek, keçi yünü, pamuk ipliği, mazı ve ilaç ürünlerinin yıllık rekolte bilgileri ve piyasa durumu başta olmak üzere önemli ticari verilerin düzenli olarak Londra'daki patron tüccarlar ile paylaşıldığı görülmektedir. Büyük bir kısmı ticari acenteler tarafından yazılan bu mektuplar ticaret tarihi bakımından büyük önem arz etmektedir. Bu belgeler ticari emtianın üretim rekoltelerini, piyasa şartları, emtianın arz ve talep durumundaki değişimleri, bu haberlere dayalı olarak yakın geleceğe dair tahminleri, ticari yaşamı doğrudan etkileyen savaş haberleri, diğer Avrupalı tüccarların Halep ve çevresindeki etkinlikleri ile rekabet ve iş birlikleri ile İngiliz tüccarların ticaret yapma usulleri hakkında önemli bilgiler ihtiva etmektedir.

SP. 110 tasnifi içindeki ikinci grubu Halep konsolosu başkanlığında kançılarya, hazinedar gibi konsolosluk memurları ve Halep'teki tüccar temsilcilerinin katılımı ile düzenli olarak toplanan konsolosluk meclisi tutanakları kayıtları oluşturmaktadır. SP. 110/54 - SP. 110/56, nolu defterler 1616-1665 y1lları arasin1, SP. 110/58-SP. 110/59 numaralı defterler ise 17681791 yıllarını kapsayacak şekilde toplam 5 cilt bulunmaktadır.

Osmanlı topraklarındaki İngiliz konsolosluk düzeni içinde Halep konsolosluğu bölgesel olarak merkezi konumda olup, Halep'in yakın çevresindeki konsolos vekilleri ile 1722'ye kadar Kıbrıs konsolos vekilliği Halep konsolosluğuna bağlı idi. Dolayısıyla Kıbrıs adası ile

\footnotetext{
45 Söz konusu bu üç defter 1696-1775 yılları arasında Levant Company Londra merkez yönetiminden Halep konsolosluğuna gönderilen yazışmaların Halep kançılaryası tarafından tutulmuş kopyalarından ibarettir.

${ }^{46} S P .110 / 86$ ve $S P$. 110/87 numaralı defterler 1766-1769 yıllarına ait olup Elçi John Murray'ın Londra'daki Secretary of State ve Levant Compnay ile yazışmalarını içermektedir. Elçi John Murray'ın İstanbul'daki faaliyetleri için bakınız; Laidlaw, The British in the Levant; Gürcan, John Murray'ın İstanbul Büyükelçiliği (1765-1775).

${ }^{47} \mathrm{Bu}$ gruplama da tarafımızca yapılmıştır.
} 
İskenderun, Lazkiye, Trablusşam ve Sayda limanlarındaki konsolos vekilleri ile liman temsilcileri ve tüm tüccar ve acentelerin ticari, idari işlemleri ve buralardaki sorunları Halep’te düzenli olarak toplanan konsolosluk meclisinde görüşülüp karara bağlanmaktaydı ${ }^{48}$. Konsololsuk meclisi şehirde bulunan İngiliz tüccarların tamamının bu meclisin doğal üyesi olmaları nedeniyle aynı zamanda İngiliz ticarethanesinin ve ulusunun karar alma organiyd. Kayitlarda genelde "Assembley of the Worshipfull Consul and Factory of Aleppo" şeklinde ifade edilen konsolosluk meclisinin kararları "minute books" başlıklı defterlere kaydedilmekteydi. Bu mecliste alınan kararlar konsolosun yetki alanındaki tüm İngiliz tüccarlar için bağlayıcıydı. Konsolosluk meclisinin şirket içi işlemlere yönelik bir karar alma merci olması yanında aynı zamanda İngiliz tüccarlarının Osmanlı yerel idarecileri ile ilişkileri, millet içinde karşılaşılan ihtilaflara dair çözümler, konsolosun kendisi de dahil şirket bünyesindeki tüm memurların ölüm veya görevden ayrılması gibi durumlarda bu memurların yerine geçici olarak birisinin atanması, avania ödemelerine karar verilmesi ve şirketin finansal yönetimi ile ilgili meselelere dair kararlar bu mecliste tartışılır, karara bağlanır ve Londra'daki şirket merkezine bildirilirdi ${ }^{49}$.

Üçüncü grup belgeler Halep kançılaryası kayıtlarından oluşmaktadır. SP. 110/60-SP. 110/66 arasındaki yedi ciltten müeteşekkil bu gruptaki defterler 1718-1811 tarihleri arasın1 kapsamaktadır. Halep ve çevresinde ticaret yapan İngiliz tüccarlar ile İngiliz konsoloslarının himayesinde bulunan Hollandalı ve Venedik gibi çeşitli millet mensupları için de başvuru mercii ve noter özelliği taşıyan ve konsolostan sonra ikinci derece önemli memur olan kançılarya ofisinin kayıtlarını ihtiva etmektedir. Kançılarya kayıtları "Register of the Chancery at Aleppo" başlıklı defterlere kaydedilmekteydi. Kançılarya noter olarak kişiler arası ticaret ve ortaklık sözleşmelerini, yeminleri, vasiyetnameleri kaydeder, konsolosluk ve şirket görevlilerinin atama ve tayin işlemlerini gerçekleştirir, ölen İngilizlerin terekelerinin tespiti, kayda geçirilmesi ve gerekli şekilde satılması veya İngiltere’ye gönderilmesi işlemlerini gerçekleştirirdi $^{50}$. Bu işlemlere ait tüm kayıtlar da kançılarya defterlerine kaydedilirdi. Tüm bu yazışmalar, Halep'teki İngilizlerin ticari ve sosyal yaşama dair ayrıntılı tasvirler içermektedir.

Dördüncü belge grubu ise sayılan ilk üç grup dışında kalan muhtelif muhtevadaki defterlerden oluşmaktadır. Bu defterlerden dikkat çekici olan ciltlerden birisi Halep'te görev yapan İngiliz papazlara ait kayıtlardan oluşmaktadır. Levant şirketi İngiliz cemaatinin dini ayinleri ve diğer vecibelerini yerine getirmeleri için çeşitli dönemlerde konsoloslukta papazlar görevlendirmiştir. Bu papazlar bir yandan dini ayinleri yönetip vaftiz, evlilik ve ölüm gibi merasimleri yönetip, kaydederken bir yandan da Arapça öğrenme ${ }^{51}$, Hristiyanlığın doğduğu coğrafyayı yakından tanıma ve ilk hristiyanlar hakkında araştırmalar yapma, eserleri inceleme ve çeşitli taşınabilir antik malzemeyi toplama imkanı bulmuşlardır ${ }^{52}$. SP. 110/70 nolu defter 1756-1800 yılları arasında Halep’te görev yapan İngiliz papazların dini görevleri çerçevesinde tuttukları İngiliz cemaatinin vaftiz, evlilik, ölüm kayıtlarından oluşturmaktadır. Geriye kalan 10 defter ise, konşimento kayıtları ${ }^{53}$ ile gemi ve navlun sigorta kayıtları gibi doğrudan ticari kayıtlar ile konsolosluk bünyesinde tutulmuş diğer muhtelif kayıtlardan ibarettir.

\footnotetext{
${ }^{48}$ Türkhan, 18. Yüzyllda Doğu Akdeniz'de Ticaret ve Haleb, s. 189-194.

${ }^{49}$ Halep konsolosluk meclisi için bakınız. Türkhan, 18. Yüzyılda Doğu Akdeniz'de Ticaret ve Haleb, s. 196-198.

${ }^{50}$ Kançılarya'nın görevleri hakkında bakınız. Türkhan, 18. Yüzyılda Doğu Akdeniz'de Ticaret ve Haleb, s. 199-200.

${ }^{51}$ Levant'taki konsolosluk merkezlerinde Arapça öğren İngilizler hakkında bakınız; Simon Mills, "Learning Arabic in the Overseas Factories: The Case of the English", The Teaching and Learning of Arabic in Early Modern Europe, Ed. Jan Loop, Alastair Hamilton, Charles Burnett, Brill pub., Leiden-Bostan 2017, s. 272-293.

${ }^{52}$ Levant'ta görev yapan İngiliz papazlar hakkında bakınız;, Laidlaw, The British in the Levant, s. 75-115.

${ }^{53} \mathrm{Bu}$ konşimento kayıtlarından SP. 110/71'e dayalı olarak 1704-1706 arasındaki dönemde İskenderun limanından Londra'ya nakledilen emtia üzerine bir inceleme için bakınız; M. Sait Türkhan, "Doğu Akdeniz'de İngiliz Ticareti:
} 


\section{STATE PAPERS (SP.) BELGELERININ ÖZELLIKKLERİ VE KAYNAK DEĞERİ}

Diplomatika, arşiv belgelerinin ortaya çıkış şartlarını, dil, şekil, içerik gibi genel özelliklerini ve dönemsel olarak bu özelliklerinde meydana gelen değişiklikleri inceleyen bir bilim dalıdır ${ }^{54}$. Bu özelliklerinden hareketle belgelerin gerçeklikleri ve tarihi kaynak olma değerleri tespit edilmektedir. Yukarıda incelenen defterlerin büyük kısmını orijinal mektupların kopyalarından oluşmasına rağmen, bu defterlerin otantikliği hususunda herhangi bir şüphe bulunmamaktadır, ancak belge özelliklerini tespit edip, içeriklerinden de hareketle tarih araştırmalarının hangi alanlarına kaynaklık edebileceklerini belirlenebilir.

SP. 97 tasnifini SP. 105 ve SP. 110 numaralı tasniflerden ayıran en önemli özelliği İngiliz elçileri tarafindan İstanbul'dan Londra'ya gönderilen resmi rapor ve orijinal mektuplardan oluşmasıdır. Bu tasnifteki ciltler söz konusu mektupların kronolojik olarak düzenlenip bir araya getirilmesinden oluşmaktadır. Ancak içinde ciltlenmeden bırakılıp dosya olarak muhafaza edilen belgelere de rastlanmaktadır. Bu mektupların İstanbul'da kaydedilmiş olması gereken resmi kopyaları ise arşivde mevcut değildir. Bu kopyalar SP. 97 içindeki eksiklikleri tamamlamaya yarayabilirdi. Ancak elçi ve konsolosların şahsi evrakları içinde bulunan resmi ve şahsi yazışmalarının kopyaları bu eksikliği tamamlayıcı olabilir ${ }^{55}$.

SP. 105 ve SP. 110 numaralı tasniflerindeki defterlerin önemli bir kısmı ise gönderilen mektupların ve resmi yazışmalarının gönderildikleri merkezdeki kopyalarının kaydedildiği defterlerden oluşmaktadır. Genel uygulama çerçevesinde gönderilen her bir mektubun kopyasının göndericisi veya gönderen birim tarafından düzenli olarak defterlere kaydedilmesi standart bir uygulamadır. SP. 105 ve SP. 110 tasnifindeki mektupların asılları ise günümüze ulaşmamış veya henüz gün yüzüne çıkmamıştır. Ayrıca Halep'teki şirket hazinedarının tüm muhasebe kayıtları ile bu hesaplarla ilgili diğer perakende evrak ve ticarethanenin diğer ticari kayıtlarının büyük bölümü de bugün arşivde mevcut değildir. Bu son durumun tek istisnası ise, bazı tüccar aileleri tarafından önce şahsi aile arşivlerinde korunmuş ve zamanla resmi arşivlere intikal etmiş belge varlığıdır ${ }^{56}$. SP. 105 ve SP. 110 numaralı tasniflerindeki kayıtların büyük bir kısmı müstakil defterler şeklinde iken içlerinde az da olsa dosyalanmak suretiyle muhafaza edilen müteferrik evraka da rastlanmaktadır ${ }^{57}$.

Öte yandan SP. 105 ve SP. 110 tasniflerindeki defterler kaydedildikleri merkezlerden de bazı izler taşımaktadırlar. Örneğin Halep'te tutulan defterlerin bir kısmının cilt süslemelerinde rastlanan İslamî motifler bu ciltlerin Halep'te yapıldığını düşündürmektedir ${ }^{58} \mathrm{Bu}$ ciltler günümüze ulaşmış nadir örneklerdendir. Zira ciltlerin bir kısmı tamir edilip korunurken ${ }^{59}$

İskenderun-Londra Hattında İngiliz Ticaret Filosu (1704-1706)", Avrasya İncelemeleri Dergisi (AVID), C. IV/1 (2015), İstanbul, s. 27-60, (https://dergipark.org.tr/iuavid/issue/23613/251494), (E.T. 01.0.2019).

${ }^{54}$ Mübahat S. Kütüoğlu, "Diplomatik", DİA, C. IX, İstanbul 1994, s. 360.

55 İlki 18. yüzyıl sonralarında ikincisi de 19. yüzyıl başlarında olmak üzere iki kez İstanbul'da elçi olarak görev yapan İskoç diplomat Robert Liston'ın tüm elçilik kariyerine ait 213 ciltten oluşan şahsi arşivi bu minvaldeki zengin içeriği ile iyi bir örnektir. Liston'ın şahsi arşivi günümüzde National Library of Scotland'da araştırmacıların araştırmacıların hizmetine sunulmuştur. Liston'a ait arşiv kataloğu için bakınız; http://manuscripts.nls.uk/repositories/2/resources/13381\#notes (E.T. 12 Haziran 2019).

56 İngiltere'de farklı merkezlerde bulunan aile arşivlerinin de etkin bir şekilde kullanıldığı, İngiliz tüccar aileleri hakkında örnek bir çalışma için bakınız; Serdaroglu, The Evolution of Commercial Institutions and Business Networks in the Ottoman Empire: British Merchant Families and Individual Merchants in the Levant Trade in the 18 th Century.

${ }^{57}$ Örneğin SP. 110/74, (1707-1781) numaralı dosya bu şekilde muhafaza edilen müteferrik evrakın dosyalandığı bir örnek olarak gösterilebilir.

${ }^{58}$ SP. 110/60, (1718-1771); SP. 110/64, (1769-1784). Bu iki defterin arka kapağının ortasında şemse bulunmaktadır.

59 SP. 110/64 nolu defterin cildinin 1934 yılında tamir edildiğine dair cilt içine yapıştırılmış bir tamir notu bulunmaktadır.

\section{History Studies}


muhtemelen daha başka örnekleri günümüze ulaşamış ve yerini sonradan arşivde yapıldığ 1 anlaşılan ve herhangi bir tarihi özellik taşımayan karton ciltlere bırakmıştır.

SP. 97 tasnifi Londra'da Secretary of State bürosundan biriken evrakın 19. yüzyılda Public Record Office'in kuruluşu aşamasında arşive aktarılmıştır. SP. 105 ve SP. 110 numaralı tasnifler ise çoğunluğunun bulunduğu Halep başta olmak üzere ilgili merkezlerden Londra'ya gönderilen belgelerden oluşmuştur. Bu aktarım dişında farklı yollarla tasnife kazandırılan yeni defterlere de rastlanmaktadır. Örneğin, SP. 110 tasnifi içindeki 86, 87 ve 88 numaralı defterler 1917 ve 1930 yıllarında yılında Foreing Office tarafından İngiltere'nin Penzance kasabasında J. A. D. Bridger isimli bir sahaftan satın alınarak arşive kazandırılmışıır ${ }^{60}$. Aynı tasnifte Levant Company ile ilgili son defterin numarası 90'dır. Defterlerin numara sırası göz önüne alındığında 89 ve 90 numaralı defterlerin de herhangi bir kayıt olmamakla birlikte, ilgili tasnife 1930'larda veya sonrasında kaydedildiği iddia edilebilir.

SP. 97 tasnifi içerik itibariyle elçiler tarafından İstanbul'dan Londra'ya gönderilen diplomatik raporlar ile diğer diplomatik yazışmalardan oluşmaktadır. Bu yazışmalar, sürdürülen diplomasinin ayrıntılarına ulaşmak için ana kaynak durumundadır. Bunlar dışında SP. 97'de elçilik merkezinde farklı gayelerler tutulan diğer bazı kayıtlara da rastlanmaktdır.

SP. 105 ve SP. 110 tasnifindeki defterler ise içerik olarak tamamen ticari mektuplar ve kayıtlardan oluşmaktadır. Muhasebe defterleri dışındaki defterlerin hemen hemen tamamı mektupların kopyalarından oluşmaktadır. Kopya defterlerinin en önemli eksiği bu mektupların içinde bahsedilen ve ekinde gönderildiği de anlaşılan bazı ayrıntılı raporlar, hesap dökümleri, gemi manifestoları, faturalar gibi önemli ticari belgelerin bulunmamasıdır. Aslında bu eksiklik kopya kayıtlar için normal olmakla birlikte, günümüz araştırmacıları için bir şanssızlıktır.

SP. 105 ve SP. 110 defterlerinden Levant Company merkezinin ve Londra'daki patron tüccarların Levant'taki konsoloslar, diğer diplomatik memurlar ve ticari acenteler ile belirli bir düzen dahilinde sürekli olarak yazışmalar yaptıkları görülür. Ticari yazışmalar genellikle bir önceki mektuptan sonra yaşanan gelişmeleri özetlemekle başlar, devamında ticari işlemlere dair genel durum, piyasasında yaşanan ticari gelişmeler, ticaretin ve şehir veya limandaki tüccarların durumu, yaşanan sorunlar ve çözümleri gibi değerlendirmeleri içerir. Ayrıca Levant piyasanın durumuna göre Londra'dan talep edilen emtia çeşitleri ile Levant'tan gönderilmesi istenen emtianın özellikleri ve kalite durumları gibi değerlendirmeler de bu yazışmalara eklenmekteydi. Bu mektuplar sayesinde temsilci veya konsolosun Londra'da kimlerle ne tür bağlantılar içinde olduğu ayrıntıları ile takip edilebilir ${ }^{61}$. Ayrıca Levant piyasasının genel durumu, ticarete konu olan emtianın miktarı net olarak tespit edilemese de arz ve talep yönelimi ve piyasanın genel eğilimleri tespit edilebilir.

$\mathrm{Bu}$ yazışmalar tarih metodolojisi itibariyle birincil kaynaklar olarak kabul edilmekle birlikte, güvenilirlikleri bakımından yine de ihtiyatlı olunması gereken durumlar da söz konusudur. Mektup yazarlarının zaman zaman gerçekleri saklama, çarpıtma gibi yollara başvurdukları görülmektedir. Örneğin acentelerin patronlara ait malları kendi malları adına piyasaya sürme, elde edilen geliri patrona aktarma yerine bulunduğu piyasada kredi faaliyetlerinde kullanma, kötü giden işleri patrondan saklama gibi bazı suistimallere tevessül ettikleri durumlara da

\footnotetext{
${ }^{60}$ Defterin J.A.D. Bridger'dan alındığını gösteren notlar ilgili defterlerin kapak içlerine yapıştırılmıştır. SP. 110/86, (Temmuz 1766-Kasım 1769); SP. 110/87, (Temmuz 1766-Haziran 1769); SP. 110/88, (1684-1691).

${ }^{61}$ Örneğin 1705 yılında İngiltere'nin Halep Konsolosu Brandon 22 Şubat 1705'te Londra'dan İskenderun limanına gelen ve Mart sonunda kalkması beklenen Drayton ticari kalyonu ile çeşitli kimselere göndermek üzere bu tür bir dizi mektup kaleme almıştır. Böylece Ağustos 1704'teki son mektuplarından bu yana Halep'te meydana gelen gelişmeleri kısaca özetleyen çoğunluğu, özel bazı kısımlar dışında birbirinin aynısıdır. Bakınız, SP. 110/23, s. 9194v., (19-24 Mart 1705).
}

\section{History Studies}


rastlanır $^{62}$. Böylesi durumların tespiti, yazışmaları belirli bir bütünlükte, cevapları ile paralel şekilde okumakla mümkün olabilir. Bu nedenle yazışmaların bir bölümüne veya bir grubuna dayanmak yerine uzun soluklu bir metin takibi olası yanıltıcı durumların önüne geçmek için elzemdir.

Yazışmaların içerik özelliklerinden başka, düzenli kayıtlar sayesinde mektuplaşma sıklığı ve posta usüllerine dair bilgi edinmek de mümkündür. Bu ticaret ağları arasındaki iletişim sıklığı, enformasyon değişimi ve ilişki biçimleri hakkında da bilgi edinmeye imkan tanır. Mektuplaşma sıklığ́ ve zaman aralığ1 dönemin ulaşım şartları çerçevesinde şekillenmekte ve özellikle gemilerin sefer zamanlarında artış gösterir. Örneğin; İskenderun'dan Londra'ya gidecek bir gemiye mal yüklenmeye başlanması geminin en kısa gelecekte limandan ayrılma zamanını işaret ederdi. Ticari acentelerin malları Halep'ten İskenderun'a gönderdikten hemen sonra, Levant şirketi idaresine ve Londra'daki patronlarına gönderilmesi gereken mektupları kaleme almak için yoğun bir çaba içine girdikleri görülmektedir. Yaşanan veya yaşanması mümkün olan en son gelişmeleri kaydedebilme adına mektupların mümkün olan en geç tarihte yazılması benimsenmişti. $\mathrm{Bu}$ mektupların başlangıcında muhataptan gelen son mektubun tarihi belirtilerek önceki karşılıklı mektuplaşma zinciriyle ilgi kurulmakta ve böylece varsa olası kopuklukların belirlenmesine imkan tanınmaktaydı. Zira dönemin ulaşım şartlarında muhatabına hiç ulaşmayan mektuplar da olabilmekteydi.

Burada dikkat çeken hususlardan birisi de bir mektubun sadece deniz yolu veya sadece karayoluyla gönderilmediğidir. Mektuplar hem kara yolu hem de deniz yoluyla gönderilmekteydi. Zira hangi alternatif ile adresine ulaşacağı veya hangi alterenatifin daha hızlı gideceği belli değildir. Kimi zaman deniz yoluyla gönderilen mektuplar daha hızlı bir şekilde Londra'ya ulaşırken kimi zaman da kara yolu veya üçüncü bir yol olarak karma bir şekilde gönderilen mektuplar daha hızlı ulaşa bilmekteydi. Halep ve diğer merkezlerden Londra'ya doğrudan deniz yolula gönderilen mektupların alternatif kopyaları önce İstanbul'daki elçiliğe ulaştırılmakta ve buradan kara yoluyla Viyana aktarmalı olarak veya deniz yoluyla doğrudan veya Venedik, Marsilya veya Livorno aktarmalı olarak Londra'ya gönderilmekteydi ${ }^{63}$. Bazı önemli ve acil mektupların ve diplomatik yazışmaların üçüncü bir kopyalarının gönderildiği durumlara da rastlanmaktadır. Halep ve İstanbul aynı zamanda Hindistan ve İran üzerinden gelen East India Company mektuplarının da aktarma merkezi oldukları için düzenli ve sürekli işleyen bir ulak ve posta sistemine sahiptiler ${ }^{64}$.

Halep ve İskenderun merkezli mektupların İskenderun'dan kalkan gemiye verilmesinden hemen sonra bu mektupların kopyalarının karayoluyla gönderilmesi için yeniden bir yazışma ameliyesine girişilirdi. Bu ikinci ve bazen üçüncü kopyaların içinde de diğer kopyaların hangi yolla gönderildiği ve geminin İskenderun'dan kalkış tarihi de genelde belirtilirdi. Benzer bir yazışma ameliyesi deniz aşırı merkezler dışında Londra'daki patron tüccarlar ve Levant Company yetkilileri için de geçerliydi. Tüm bu süreçlerde her bir mektubun tasarlanması, daha önce alınan notlar çerçevesinde kaleme alınması, çoğaltılması tüccarların ve katiplerinin diğer işleri yanında önemli bir meşguliyetti.

\footnotetext{
${ }^{62}$ Benzer şekilde hareket ederek iflasa sürüklenen William Harvey hakkında bakınız; Türkhan, 18. Yüzyılda Doğu Akdeniz'de Ticaret ve Haleb, s. 114-119.

${ }^{63}$ SP. 110/22, s. 116, Halep'ten Londra'ya, Edmund Dunch'a, /6 March 1702/17 March 1702), SP. 110/22, s. 108v109, Halep'ten Londra'ya, Bay Thomas Cary'ye, (17 February 1702/28 February 1702).

${ }^{64}$ Halep konsolosluğu Hindistan ve İran coğrafyası ile Londra arasında gelip giden East India Company'ye ait mektupların ana aktarım merkezlerinden birisiydi. British Library (BL.), India Office Records (IOR.) E/1/6, s. 209, (31 October 1715/11 November 1715); IOR. E/1/70, s. 232-233v (10 April 1782/21 April 1782).
} 
SP. 105 ve SP. 110 numaralı tasnifler içinde özellikle acenteler ve tüccarlar arası özel yazışmaları ihtiva eden mektuplara bolca rastlanmaktadır. Bu mektuplar resmi olmayan, ticari yazışmalardır ve yazarı ile muhatabı arasındaki samimiyet ve yakınlık, bu çoğu kez kardeş veya yakın akraba olma derecesine göre yalın, sade ve samimi bir dilde yazılmışlardır. Bu nedenle ticari ve özel yaşama dair şikayetler ve memnuniyetler çoğu kez bu mektuplara net ve samimi bir üslupla yansımıştır ${ }^{65}$. Öte yandan Levant Company Londra merkez idaresi ile İstanbul'daki elçilik makamı ve diğer konsolosların birbirleri ile yazışmalarının kopyaları ise daha resmi bir dille kaleme alınmıştır. Bu mektuplar dışında konsolosluk meclisi ve kançılarya kararlarının ve kayıtlarının tutulduğu defterler de yine resmî belgeler olarak kendine has resmi ve diplomatik dil özelliklerini haizdir.

18. yüzyıla ait kayıtların hemen hemen tamamı İngilizce olup bazı defterler içinde az da olsa İtalyanca yazışmalara da rastlanmaktadır. Kullanılan İngilizce günümüz İngilizcesine oldukça yakın olup bazı kelime gurupları ve edatlar için o döneme ait el yazısında kullanılan kısaltmalar yaygın bir biçimde kullanılmıştır. Bunun dışında bazı kelimelerin imlasında (spelling) bugünküne göre bazı küçük farklılıklar görülmekle birlikte bunlar anlaşılması güç farklılıklar değildir. Defterler çoğu kez okunaklı bir yazı ile yazılmıştır. Ancak bazı kötü yazan kâtiplerin yazılarını kimi zaman okumak zor olabilmektedir. Defterlerdeki el yazılarının sürekliliği kayıtların büyük çoğunluğunun uzunca bir süre tek bir kâtip tarafından tutulduğunu göstermektedir. Öte yandan su, nem gibi olumsuz etkilere maruz kalarak cildi şekilde yıpranan, mürekkeb rengi solan veya dağılan veyahut başka sebeplerle kenarları kopan bu sebeple de okunması oldukça güç olan veya okunamayan ciltlere de rastlanmaktadır. Yıpranmış da olsa söz konusu üç tasnifin tamamı gerekli restorasyonları yapılmış vaziyette araştırmacıların hizmetine sunulmuştur.

\section{Sonuç}

Sonuç olarak, TNA'in Osmanl-İngiliz diplomatik ve ticari ilişkileri tarihi bakımından önemli bir tasnifi olan SP. tasnifindeki belgeler SP. 97, SP. 105 ve SP. 110 numaralı üç alt tasnifte bulunmaktadır. Bunlardan SP. 97 diplomatik yazışmaları içermektedir ve iki devlet arasında diplomatik ilişkiler için ana kaynak durumundadır. SP. 105 tasnifi ise Levant Company merkez idaresinden Osmanlı topraklarındaki İngiliz tüccarlar ve diplomatik temsilcilere gönderilen emir ve yazışmaların kopyalarını ve İstanbul elçiliği kançılarya ve şirket hazinedarının kayıtları ile Londra'da şirket tarafından tutulan ithalat-ihracat verilerine ait kayıtları muhtevidir. SP. 110 tasnifinde ise Halep merkezli ticari ve diplomatik yazışmaların kopyaları, Halep konsolosluk meclisi tutanakları ve kançılarya kayıtları içermektedir. Bu belgeler ve defterler iki devlet arasındaki cereyan eden ticareti anlamak bakımından birincil kaynaklardır. Aynı zamanda ticari faaliyetlerin sürdürüldüğü başta İstanbul olmak üzere İzmir ve Halep gibi diğer önemli Osmanlı şehirleri ile Kıbrıs adası ve Doğu Akdeniz kıyısındaki İskenderun, Sayda, Lazkiye, Beyrut ve Akka gibi liman şehirleri tarihi için de önemli kaynaklardır.

Günümüze ulaşan SP. belgeleri daha çok İstanbul, Halep, İskenderun, Kıbrıs ve bir miktar da İzmir merkezli olanlardır. Kahire, Selanik ve Ege adalarındaki İngiliz ticaret merkezleri ve konsolosluklarında kaleme alınan veya kopyalanan mektuplar arşivde mevcut değildir. Ancak bu merkezlerde de İngiliz konsolosluğu veya ticari acentelerinin bulunduğu Londra'dan bu merkezlere gönderilen mektupların kopyalarından anlaşılmaktadır. Bu merkezlerde üretilen

\footnotetext{
${ }^{65}$ Örneğin SP. 110/22 numaralı defter Halep'te ticari acente Samuel Harvey tarafından kaleme alınan mektupların kopyalarını içermektedir. Samuel Harvey kardeşi John Harvey, başka İngiliz ve Hollandalı tüccarlar adına Halep'te ticaret yapmaktaydı. Harvey'in kimi mektupları ticari konular başta olmak üzere Halep'ten olup bitenler hakkında başta kardeşi ve diğer muhataplarına samimi bir üslup ile kaleme alınmıştır.
} 
evrak ve mektuplar Londra'ya ulaşamadı̆̆ için veyahut da muhafaza edilemediği için günümüzde ulaşmamış olabilir. Umulur ki, bunlar da bir gün gün yüzüne çıktı̆̆ında bu merkezlerdeki İngiliz diplomatik ve ticari faaliyetlerine dair daha ayrıntılı bilgiler edinmemiz mümkün olacaktır. Belgeler üzerine yaplacak farklı yöndeki analitik çalışmalar Londra bağlantılı Levant-İngiliz ticaret ağının yapısal özellikleri, emtia çeşitliliği, ithalat-ihracat, gemicilik, navlun gibi ticari meseleler, uluslararası hukuk ve diplomatik ilişkiler üzerine yeni sonuçlara ulaşmayı mümkün kılacaktır.

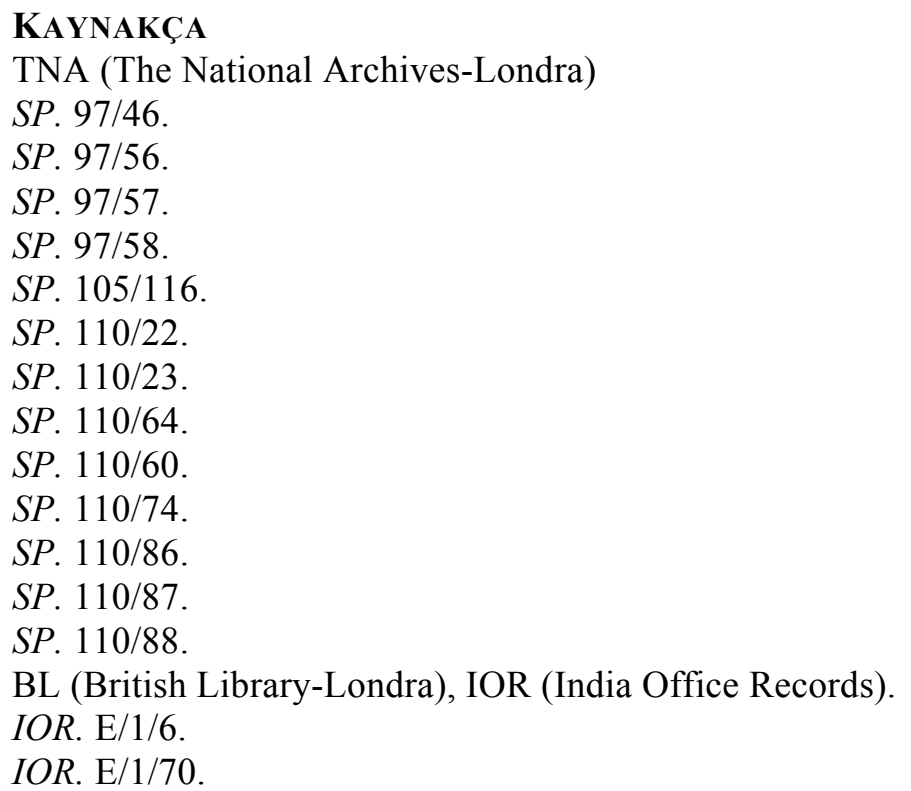

Makale ve Kitaplar

ABBOTT G. F., Under the Turk in Constantinople; a Record of Sir John Finch's Embassy, 1674-1681, Macmillan and Co., London 1920.

ALTINÖZ İsmail, "Londra The National Archives'de Ankara ile İlgili Belgeler Üzerine bir Değerlendirme", Tarihte Ankara Uluslar Arası Sempozyumu, Bildiriler Ankara 25-26 Ekim 2011, c. II, Ankara 2012, s. 987-999.

ALTINTAŞ Abdulmennan Mehmet, Kizlldeniz'den Akdeniz'e: Ticaret, Diplomasi ve Güzergâhlar (1600-1700), (İstanbul Üniversitesi Sosyal Bilimler Enstitüsü, Basılmamış Doktora Tezi), İstanbul 2016.

AMBROSE Gwilym Prichard, The Levant Company Mainly from 1640-1753, (Oxford Univeristy Unpublished $\mathrm{PhD}$. Thesis), Oxford 1935.

ANDERSON Sonia P., An English Consul in Turkey: Paul Rycaut at Smyrna, 1667-1678, Clarendon Press, Oxford 1989.

BAĞIŞ Ali İhsan, Britain and the Struggle for the Integrity of the Ottoman Empire: Sir Robert Ainslie's Embassy to Istanbul 1776-1794, The Isis Press, İstanbul 1984.

Başbakanlık Osmanlı Arşivi Rehberi, (haz. Yusuf ihsan Genç, vd.), Başbakanlık Basımevi, İstanbul 2010.

BERRIDGE G. R., British Diplomacy in Turkey 1583 to Present a Study in the Evolution of 
Resident Embassy, Martinus Nijhoff Pub., Leiden 2009.

BÜYÜKAKSOY Ahmet, Ingiltere'nin İstanbul Elçisi Thomas Roe'nun Diplomatik Yazlşmaları (1621-1628), (Marmara Üniversitesi Türkiyat Araştırmaları Enstitüsü Basılmamış Yüksek Lisans Tezi), İstanbul 2012.

BÜYÜKAKSOY Ahmet, James Porter'ın İstanbul Büyükelçiliği (1747-1762), (Marmara Üniversitesi Türkiyat Araştırmaları Enstitüsü Basılmamış Doktora Tezi), İstanbul 2016.

BÜYÜKAKSOY Ahmet, “İngiltere'nin İstanbul Elçisi Sir Everard Fawkener’in Kaleme Aldığ 1731-1738 Y1lları Arasındaki Hadiseleri Anlatan Bir Rapor", Yeditepe Üniversitesi Tarih Bölümü I. Uluslararası Türk Kültürü ve Tarihi Sempozyumu Bildiri Kitabı, Ed. Ahmet Taşağıl, Aykut Kar, Ahmet Büyükaksoy, Ayşen Müderrisoğlu, yy., ty., s. 452472 ,

https://www.academia.edu/39833534/\%C4\%B0NG\%C4\%B0LTERE N\%C4\%B0N \% C4\%B0STANBUL EL\%C3\%87\%C4\%B0S\%C4\%B0 S\%C4\%B0R EVERARD FA WKENER \%C4\%B0N KALEME ALDI\%C4\%9EI 1731-

1738 YILLARI ARASINDAK\%C4\%B0_HAD\%C4\%B0SELER\%C4\%B0_ANLAT AN B\%C4\%B0R_RAPOR,_(E.T. 12 Temmuz 2019).

Calendar of State Papers, Foreign Series, of the Reign of Edward VI., 1547-1553, Preserved in the State Papers Department of Her Majesty's Public Record Office, Edt. William B. Turnbull, Longman, Green, Longman, \& Roberts pub., London 1861.

COOPER Charles Purton, An Account of the Most Important Public Records of Great Britain and the Publications of the Record Commissioners together with other Miscellaneous Historical and Antiquarian Information Compiled from Various Printed Books and Manuscripts, vol II, Baldwin and Cradock, London 1832.

DAVIS Ralph, Aleppo and Devonshire Square: English Traders in the Levant in the Eighteenth Century, Macmillan pub., London 1967.

DEMIRYÜREK Mehmet, Ottoman Documents on the English in the Ottoman Empire (17001800), The Isis Press, İstanbul 2017.

DERELI Hamit, Kraliçe Elizabeth Devrinde Türkler ve İngilizler, Ankara Üniversitesi Dil ve Tarih Coğrafya Fakültesi yay., Ankara 1951.

ELDEM Edhem, Daniel Goffman, Bruce Masters, Doğu ile Batı Arasında Osmanlı Kenti: Halep, İzmir ve İstanbul, Tarih Vakfi yay., İstanbul 2003.

ELİBOL Numan, Erol Özvar, "The Anglo-Ottoman Trade 1700-1800: Goods, Volume and Balance of Trade", https://ata.boun.edu.tr/ahec/conferencepapers2014/ElibolOzvar.pdf (E.T. 20 Mart 2016).

EPSTEIN Mortimer, The Early History of the Levant Company, George Routledge\&Sons Limited, London 1908.

ERSOY Osman, “İngiliz Devlet Arşivi (The Public Record Office)”, Türk Kütüphaneciler Derneği Bülteni, c. IV/2, Ankara 1955, s. 125-131.

FRANGAKIS-SYRETT Elena, The Commerce of Smyrna in the Eighteenth Century (17001820), Centre for Asia Minor Studies pub., Athens 1992.

GOFFMAN Daniel, Osmanlı Imparatorluğu'nda İngilizler 1642-1660, Çev. Ayşe Başç1Sander, Sabanc1 Üniversitesi yay., İstanbul 2001. 
GÜRCAN Fatih, John Murray'ın İstanbul Büyükelçiliği (1765-1775), (Marmara Üniversitesi Türkiyat Araştırmaları Enstitüsü Basılmamış Doktora Tezi), İstanbul 2014.

İNALCIK Halil, "İmtiyâzât (The Otoman Empire)”, Encyclopedia of Islam, c. III, E. J. Brill, Leiden 1986, s. 1179-1189.

KOCABAŞOĞLU Uygur, Majestelerinin Konsoloslart: İngiliz Belgeleriyle Osmanlı İmparatorluğu’ndaki İngiliz Konsolosluklarl 1580-1900, İletişim yay., İstanbul 2004.

KÖPRÜLÜ Orhan F., "Türkler ve Türkiye Hakkında Bilinmeyen veya Az Bilinen İngilizce Kaynaklar", Cumhuriyetin 50. Yllına Armağan, Türk Kültürünü Araştırma Enstitüsü yay., Ankara 1973, s. 159-174.

KURAT Akdes Nimet, Türk-Ingiliz Münasebetlerine Klsa Bir Baklş: 1553-1952, Ankara Üniversitesi Dil ve Tarih Coğrafya Fakültesi yay., Ankara 1952.

KURAT Akdes Nimet, The Despatches of Sir Robert Sutton Ambassador in Constantinople (1710-1714), Royal Historical Society, London 1953.

KURAT Akdes Nimet, "İngiliz Devlet Arşivinde Kütüphanelerinde Türk Tarihine Ait Bazı Malzemeye Dair", AÜ. DTCF. Dergisi, c. VII/1 (Mart 1949), s. 1-27.

KUTLUOĞLU Muhammed Hanefi, "İngiliz Devlet Arşivi (PRO) ve Yakın Dönem Osmanlı Tarihi Açısından Önemi”, Osmanlı Araştırmaları, c. XVIII, (İstanbul 1998), s. 225238.

KÜTÜKOĞLU Mübahat S., "Ahidname (Türk Tarihi)”, Diyanet İslam Ansiklopedisi (DIA.), c. I, İstanbul 1988, s. 536-540.

KÜTÜKOĞLU Mübahat S., Balta Limanı'na Giden Yol: Osmanl-İngiliz İktisadi Münasebetleri (1580-1850), TTK yay, Ankara 2013.

LAIDLAW Chirtine, The British in the Levant: Trade and Perception of the Ottoman Empire in the Eighteenth Century, I. B. Tauris, London 2010.

LELLO Henry, The Report of Lello: Third English Ambassador to the Sublime Porte, Babrali Nezdinde Üçüncü İngiliz Elçisi: Lello'nun Muhtırası, Edt. Orhan Burian, Ankara Üniversitesi Dil ve Tarih Coğrafya Fakültesi yay., Ankara 1952.

LOMAS S. C., "The State Papers of the Early Stuarts and the Interregnum", Transactions of the Royal Historical Society, New Series, vol. XVI, (1902), s. 97-132.

MILLS Simon, "Learning Arabic in the Overseas Factories: The Case of the English", The Teaching and Learning of Arabic in Early Modern Europe, Ed. Jan Loop, Alastair Hamilton, Charles Burnett, Brill pub., Leiden-Bostan 2017, s. 272-293.

RENTON Alexander Wood, vd., (ed.) Encyclopcedia of the Laws of England with Forms and Precedents by the Most Eminent Legal Authorities, vol. XIII, William Green and Sons, Edinburgh 1908.

RIORDAN Michael, "The State Papers and the Writing of History in Early Seventeenth Century England", (edt. Maria Pia Donato, Anne Saada), Pratiques d'Archives à l'époque Moderne. Europe, Mondes Coloniaux, s. 69-93, Doi: 10.15122/isbn.978-2406-08555-3.p.0069, (E.T. 12 Temmuz 2019).

ROSEDALE Honyel G., Queen Elizabeth and the Levant Company: A Diplomatic and Literary Episode of the Establishment of our Trade with Turkey, Henry Frowde pub., London 1904. 
RUSSELL Ina S., The Later History of the Levant Company 1753-1825, (The Victoria University of Manchester, Unpublished PhD Thesis), 1935.

SERDAROĞLU Uzeyir Serdar, The Evolution of Commercial Institutions and Business Networks in the Ottoman Empire: British Merchant Families and Individual Merchants in the Levant Trade in the 18th Century, (University of Birmingham Unpublished PhD Dissertation), Birmingham 2018.

State Papers Published under the Authority of his Majesty's Commission, vol. I, London 1831.

State Papers Published under the Authority of her Majesty's Commission, vol. IX, London 1849.

State Papers Published under the Authority of her Majesty's Commission, vol. XI, London 1852.

SKILLITER Susan A., William Harborne and the Trade with Turkey 1578-1582: A Documentary Study of the First Anglo-Ottoman Relations, British Academy pub., London 1977.

TALBOT Michael, British Ottoman Relations 1661-1807: Commerce and Diplomatic Practice in Eighteenth-Century Istanbul, Boydell Press, Woodbridge 2017;

TÜRKHAN M. Sait, 18. Yüzyllda Doğu Akdeniz'de Ticaret ve Haleb, (İstanbul Üniversitesi Sosyal Bilimler Enstitüsü Basılmamış Doktora Tezi), İstanbul 2014.

TÜRKHAN M. Sait, "Doğu Akdeniz'de İngiliz Ticareti: İskenderun-Londra Hattında İngiliz Ticaret Filosu (1704-1706)", Avrasya Incelemeleri Dergisi (AVID), C. IV/1 (2015), İstanbul, s. 27-60, (https://dergipark.org.tr/iuavid/issue/23613/251494), (E.T. 01.0.2019).

ÜLKER Necmi, "XVII. Yüzyılın İkinci Yarısında İzmir'deki İngiliz Tüccarına Dair Ticari Problemlerle İlgili Belgeler", Belgeler-Türk Tarih Belgeleri Dergisi, c. XIV/18 (19891992), TTK yay., Ankara 1992, s. 261-319+44.

ÜNVER Metin, "Son Dönem Osmanlı Tarihi Araştırmaları Açısından İngiliz Milli Arşivi ve Arşiv Belgelerinin Önemi”, Avrupa Arşivlerinde Osmanlı Imparatorluğu, (edt. Yonca Köksal-Mehmet Polatel), İstanbul 2014, s. 105-121.

VAN DEN BOOGERT Maurits H., Kapitülasyonlar ve Osmanlı Hukuk Sistemi: 18. Yüzyılda Kadılar, Konsoloslar ve Beratları, Çev. Ali Coşkun Tuncer, Türkiye İş Bankası Kültür yay., İstanbul 2014.

VLAMI Despina, Trading with the Ottomans: The Levant Company in the Middle East, I. B. Tauris, London 2015.

WALNE Peter, “The Record Commission 1800-37”, Prisca Munimenta. Studies in Archival and Administrative History presented to Dr. A. E. J. Hollaender, Edt. Felicity Ranger, University of London press., London 1973.

WEBB Nigel, Caroline Webb, Earl and his Butler in Constantinople: The Secret Diary of an English Servant among the Ottomans, I. B. Tauris, London 2009.

WOOD, Alfred C., A History of the Levant Company, Frank Cass\&Co., London 1964.

YALÇINKAYA Mehmet Alaaddin, The First Permanent Ottoman-Turkish Embassy in Europe: The Embassy of Yusuf Agah Efendi to London (1793-1797), Eren yay, İstanbul 2002. 
YALÇINKAYA Mehmet Alaaddin, “18. Yüzyılın Son Çeyreğinde İngiliz Arşivinde Bulunan Osmanlı Devleti Hakkındaki Arşiv Belgeleri”, II. Uluslararası Osmanlı Coğrafyası Arşiv Kongresi Bildiriler, c. 1, Ankara 2019, s. 683-700.

YAZAR Hakan, “Düvel-i Ecnebiye Defterleri: Oluşum Süreci, İçeriği ve İngiltere’ye ait XVIII. Yüzyıl Defterleri”, Diplomasi ve Dış Politika Araştırmalarında Arşivlerin Rolü Uluslararası Sempozyumu Bildiriler, Haz. Duygu Türker Çelik, Aslı Akdoğanbulut İnsan), Ankara 2017, s. 195-214.

\section{İnternet Sayfaları}

The National Archive (TNA) State Papers (SP.) tasnifinin genel özellikleri hakkında bakınız: http://www.nationalarchives.gov.uk/help-with-your-research/research-guides/statepapers-foreign-1509-1782/, (E.T. 12 Temmuz 2019).

The National Archive (TNA) Foreign Office (FO.) tasnifi hakkında bakını: http://www.nationalarchives.gov.uk/help-with-your-research/research-guides/foreigncommonwealth-correspondence-and-records-from-1782/, (E.T. 12 Temmuz 2019).

FO. 881/10007, (Persia\&Turkey: Treaties between Persia and Turkey, 1639-1822) hakkında bakınız: https://discovery.nationalarchives.gov.uk/details/r/C3662690, $\quad$ (E.T. 12 Temmuz 2019) veya

FO. 881/280, (Turkey: Abstract. Russia and Turkey. Treaties, 1774-1849) hakkında bakınız: https://discovery.nationalarchives.gov.uk/details/r/C3659811, (E.T. 12 Temmuz 2019).

SP. 97 tansifi hakkında genel bilgi için bakınız: https://discovery.nationalarchives.gov.uk/details/r/C13636, (E.T. 12.06.2019).

SP. 105 tasnifi hakkındaki bilgi için bakınız: https://discovery.nationalarchives.gov.uk/details/r/C13644, (E.T. 12.06.2019).

Robert Liston'a ait arşiv kataloğu için bakını: http://manuscripts.nls.uk/repositories/2/resources/13381\#notes, (E.T. 12 Haziran 2019). 